\title{
The Parameters of Administrative Reason Giving
}

Alexander W. Resar*

\section{INTRODUCTION: JUDICIAL REVIEW OF AGENCY REASON GIVING}

The question of what factors an agency may rely upon to justify a particular implementation of a statutory mandate underpins much of administrative law. ${ }^{1}$ Whether reviewing the Environmental Protection Agency's implementation of national primary ambient air quality standards under the Clean Air Act's mandate to establish levels "requisite to protect the public health" or the Social Security Administration's interpretation of disability under the Social Security $\mathrm{Act}^{3}{ }^{3}$ a court must engage the justifications an agency provided for its action. In this way, agency reason giving facilitates judicial control of administration, ${ }^{4}$ and judicial assessment of an agency's reasons necessarily entails assessment of the factors upon which an agency relied to reach any particular conclusion. ${ }^{5}$

Administrative reason giving occurs within statutory and political contexts that determine the sufficiency of reasons an agency provided. If the judicial review that administrative reason giving facilitates is to have

*Law clerk, United States Court of Appeals for the Tenth Circuit. Yale Law School, J.D. 2017. I am grateful to Nicholas Parrillo for providing guidance on this project. Thanks also to Nancy Musick and the editors of the Kansas Law Review for their careful and considered editing. Any errors are my own.

1. See Richard J. Pierce Jr., What Factors Can an Agency Consider in Making a Decision?, 2009 Mich. St. L. Rev. 67, 68 (2009) [hereinafter Pierce, Factors an Agency Can Consider]; JerRY L. Mashaw \& DAVID L. HARfst, The Struggle For Auto SAFety 214-15 (1990); Richard J. Pierce, Jr., How Agencies Should Give Meaning to the Statutes They Administer: A Response to Mashaw and Strauss, 59 ADMIN. L. REV. 197, 204 (2007) [hereinafter Pierce, How Agencies Should Give Meaning]. Few scholars and even fewer courts have formulated the question so explicitly, despite the undeniable fact that an understanding of the permissible justifications for agency decisions under judicial review forms the foundation of any theory of administrative law.

2. 42 U.S.C. $§ 7409$ (b)(1) (2012). See, e.g., Whitman v. Am. Trucking Ass'ns, 531 U.S. 457, $472(2001)$.

3. 42 U.S.C. $\S \S 401-434$ (2015).

4. Jerry L. Mashaw, Reasoned Administration: The European Union, the United States, and the Project of Democratic Governance, 76 GEO. WASH. L. REV. 99, 111 (2007) (noting that reason giving is a "protector of judicial review," while simultaneously arguing reason giving is best understood as an individual right that renders those individuals upon which the law subjects rather than objects).

5. Id. at 108 
any substantive component, courts must impose some limits upon the reasons sufficient to justify an administrative outcome. In other words, substantive judicial review of administration requires more than "that agencies act based on reasons," as some suggest is sufficient. ${ }^{6}$ The reasons an agency provides for an administrative outcome matter. If the Department of Justice's Antitrust Division issued a new guideline revising the Division's understanding of consumer welfare relying upon recent developments in the field of economics, those guidelines would be far more likely to survive judicial review than if those same revisions were justified as part of a politically-motivated attack by President Trump's administration on Jeff Bezos - the Amazon CEO and owner of a newspaper Trump has attacked for its unfavorable coverage of his campaign. ${ }^{7}$ Because most statutes cannot and do not exhaustively list the reasons upon which an agency may rely in support of any given administrative outcome, ${ }^{8}$ the task of establishing the parameters of administrative reason giving has fallen to the judiciary.

Unsurprisingly, then, the question of permissible considerations has been, if at times implicit, central to the contestation between technocracy and political accountability that has occupied most recent attempts to legitimate judicial review of the administrative state. ${ }^{9}$ Proponents of prioritizing democratic accountability as the foundational principle of judicial review of administrative action argue in favor of increased presidential involvement in administrative processes, generally claiming that courts should accept presidential direction of administrators as a permissible if not always decisive factor in agency decision-making. ${ }^{10}$ Building upon then-Professor Kagan's seminal article Presidential Administration, ${ }^{11}$ this argument contends that presidential involvement in

6. Jacob Gersen \& Adrian Vermeule, Thin Rationality Review, 114 Mich. L. ReV. 1355, 1406 (2016).

7. See, e.g., Marc Fisher, Why Trump went after Bezos: Two Billionaires Across a Cultural Divide, WASH. PO. (April 5, 2018), https://www.washingtonpost.com/politics/why-trump-wentafter-bezos-two-billionaires-across-a-cultural-divide/2018/04/05/22bb94c2-3763-11e8-acd5-

35eac230e514_story.html?noredirect=on\&utm_term $=.490 \mathrm{a} 1 \mathrm{c} 750381 \quad[\mathrm{https}: / /$ perma.cc/3FFKUHLY].

8. MASHAW \& HARFST, supra note 1 , at 214.

9. See, e.g., Jerry L. Mashaw \& David Berke, Presidential Administration in a Regime of Separated Powers: An Analysis of Recent American Experience, 35 YALE. J. ON REG. 549, 594 (2018).

10. That presidential rather than congressional control is the favored source of politically accountable administration was not always axiomatic; only when the Reagan administration sought to implement its broad, deregulatory agenda did presidential administration become the dominant explanation for politically accountable administration. Elena Kagan, Presidential Administration, 114 HARV. L. REV. 2245, 2247-48 (2001).

11. Id. 
and even control of administrative processes legitimates the "headless 'fourth branch' of government"12 by rendering administrators accountable to the President, who is in turn accountable to the American people for those administrative determinations. ${ }^{13}$ Presidential involvement in both formal and informal rulemaking ${ }^{14}$ infuses administration with the political perspective necessary to dictate the value judgments for which agency expertise alone cannot account, thereby rendering administration more effective, and with a more direct link to the democratic process. This valuation of judicial priorities in review of administration finds doctrinal expression in the Chevron doctrine, ${ }^{15}$ especially in the doctrine's earliest iterations. ${ }^{16}$ Two arguments regarding judicial review of administration follow from this emphasis on political control. First, that agencies should usually consider presidential direction as a decisive factor. Second, that courts should grant deference to an agency's derivation of the permissible factors for consideration, including political control, from the agency's authorizing statute, to facilitate such political control of administration reviewing.

On the other hand, proponents of technocracy or expertise-forcing ${ }^{17}$ as the motive that should animate judicial review of administrative action

12. PRESIDENT's COMM. ON ADMIN. MANAGEMENT, REPORT With SPECIAL StUdies 29 (1937) (citations omitted) (known as the BROWNLOW REPORT).

13. Kagan, supra note 10, at 2331-32.

14. Almost all scholars would agree with Kagan's declaration that "the analysis [in favor of presidential involvement in administration] with respect to adjudications, however, is fundamentally different ...."Id. Proponents of the unitary executive may constitute an exception; in its most reductive form, the argument for the unitary executive claims that the Constitution mandates presidential control over all executive actors. See Christopher S. Yoo, Steven G. Calabresi \& Anthony J. Colangelo, The Unitary Executive in the Modern Era, 1945-2004, 90 IOWA L. REV. 601, 628-30 (2005). In response, some commentators claim that presidential involvement in adjudication would violate the Administrative Procedure Act, the Constitution, or both. See, e.g., Harold J. Krent, From a Unitary to a Unilateral President, 88 B.U. L. REV. 523, 549 (2008).

15. Chevron, U.S.A., Inc. v. Nat. Res. Def. Council, Inc., 467 U.S. 837, 865 (1984). See also Kathryn A. Watts, Proposing a Place for Politics in Arbitrary and Capricious Review, 119 YALE L.J. 2, 38 (2009) [hereinafter Watts, Proposing a Place] (arguing that "Chevron underscored the relevance of political influences (and political accountability) to agencies' interpretive processes" and thus "anchored the presidential control model." (internal quotation marks omitted)). As we will see, however, this is not the only viable reading of Chevron. See Peter L. Strauss, Overseer, or "The Decider"? The President in Administrative Law, 75 GEO. WASH. L. REV. 696 (2007).

16. See Jodi L. Short, The Political Turn in American Administrative Law: Power, Rationality, and Reasons, 61 DUKE L.J. 1811, 1814 n.9 (2012); Kagan, supra note 10, at 2372-73.

17. I borrow this term from Jody Freeman \& Adrian Vermeule, Massachusetts v. EPA: From Politics to Expertise, 2007 SuP. CT. REV. 51, 52 (2007). Freeman and Vermeule define expertise forcing as "the attempt by courts to ensure that agencies exercise expert judgment free from outside political pressures, even or especially political pressures emanating from the White House or political appointees in the agencies." Id. 
argue courts should discourage presidential involvement that all too often seeks to subjugate reasoned decision-making to the whims of presidential politics. This argument contends that political interference degrades rather than enhances the legitimacy and efficacy of administration, meaning courts should require agencies evaluating potential courses of action pursuant to statutory authorizations to consider only those factors that Congress expressly authorized the agency to consider. ${ }^{18}$ Proponents of judicial review as a vehicle for expertise-forcing argue that political involvement will only impact administrative decision-making in those instances where the administrative outcome desired by the President diverges from the administrative outcome that would emerge from purely technocratic deliberation, and therefore rendering agency determinations more arbitrary. ${ }^{19}$ Accordingly, commentators concerned with agency expertise argue that Presidential involvement undermines both: (1) the efficacy of the administrative process by encouraging technically inferior outcomes that lack expert support, and (2) the democratic legitimacy of the administrative state by decoupling agency determinations from the permissible considerations contained in the relevant authorizing statutes. $^{20}$ Expertise forcing and technocracy find doctrinal expression in cases such as Massachusetts v. Environmental Protection Agency ${ }^{21}$ and Motor Vehicle Manufacturers Ass'n v. State Farm Mutual Insurance Co. ${ }^{22}$ which broadly hold that an agency must consider only those factors that Congress either expressly included in the authorizing

18. Massachusetts v. EPA, 549 U.S. 497, 528, 532-33 (2007) (holding the EPA's action was "arbitrary, capricious ... or otherwise not in accordance with law" because the EPA's justifications for claims that it would be unwise to regulate greenhouse gases "rests on reasoning divorced from the statutory text." (internal quotation marks omitted) (citations omitted)).

19. See, e.g., Peter M. Shane, Chevron Deference, the Rule of Law, and Presidential Influence in the Administrative State, 83 FORDHAM L. REV. 679, 698-99 (2014); Lisa Schultz Bressman, Beyond Accountability: Arbitrariness and Legitimacy in the Administrative State, 78 N.Y.U. L. REV. 461 (2003) [hereinafter Bressman, Beyond Accountability]; Freeman \& Vermeule, supra note 17, at 88.

20. See Lisa Schultz Bressman, Deference and Democracy, 75 GEO. WASH. L. REV. 761, 781 (2007).

21. Freeman and Vermeule compellingly argued that expertise-forcing animates the majority's decision in Massachusetts v. EPA, where the majority held that the EPA "offered no reasoned explanation for its refusal to decide whether greenhouse gases cause or contribute to climate change [and must therefore be regulated as pollutants under the Clean Air Act]." Freeman \& Vermeule, supra note 17, at 63-64 (quoting Massachusetts v. EPA, 549 U.S. at 534) (emphasis added). According to Freeman and Vermeule, pressure from President Bush prevented the EPA from making the determination with overwhelming support in the scientific record: that greenhouse gas emissions endanger public health or welfare. Id. at 64. See also Lisa Heinzerling, The FDA's Plan B Fiasco: Lessons for Administrative Law, 102 GEO. L.J. 927 (2014) (summarizing the "Plan B Cases").

22. Motor Vehicles Mfrs. Ass'n v. State Farm Mut. Auto. Ins. Co., 463 U.S. 29 (1983). 
statute, ${ }^{23}$ or intended the agency to consider. ${ }^{24}$

Most scholars have treated technocracy and political accountability as fundamentally incompatible even if mutually desirable. ${ }^{25}$ Courts have sought to maximize the expression of both expertise and accountability within whichever particular hierarchy of values a given court or commentator espouses. ${ }^{26}$ Accordingly, these two fundamental concerns provide metrics to evaluate the doctrines, both real and imagined, that seek to provide a framework for courts to address the following three questions concerning the factors an agency may consider when acting pursuant to a statutory delegation: (1) what factors may an agency consider when implementing its statutory authorization, (2) what factors may an agency decisively rely upon to justify any administrative action in the formal or informal record upon which judicial review rests, and (3) how should courts, in review of agency actions, evaluate an agency's derivations of permissible and impermissible factors for consideration from the statute authorizing a particular administrative action. The answers to these three questions could vary depending on the agency, ${ }^{27}$ the statutory language in question, ${ }^{28}$ and type of extra-statutory factor the agency considered or argued dispositive, ${ }^{29}$ or the way in which the agency arrived at its conclusion. ${ }^{30}$ Nonetheless, a court's prioritization

23. Massachusetts v. EPA, 549 U.S. at 532-33. Strangely, the Court in Massachusetts v. EPA declines to cite State Farm even once, perhaps due to the slight modification of arbitrary and capricious review employed in the former.

24. State Farm, 463 U.S. at 43 . ("Normally, an agency rule would be arbitrary and capricious if the agency has relied on factors which Congress has not intended it to consider....").

25. David J. Barron, From Takeover to Merger: Reforming Administrative Law in an Age of Agency Politicization, 76 GEO. WASH. L. REV. 1095, 1096 (2008).

26. Adrian Vermeule, Bureaucracy and Distrust: Landis, Jaffe, and Kagan on the Administrative State, 130 HARV. L. REV. 2463, 2487 (2017).

27. Whether, for example, the agency is an executive or independent agency. See infra Section III.C.

28. See, e.g., Luminant Generation Co. v. EPA, 675 F.3d 917, 926 (5th Cir. 2012) ("It is beyond cavil that the EPA may consider only the requirements of the CAA when reviewing SIP submissions. The act provides that the EPA 'shall approve [a SIP] submittal as a whole if it meets all of the applicable requirements of [the Act].' This statutory imperative leaves the agency no discretion to do anything other than ensure that a state's submission meets the CAA's requirements...." (citations omitted)). See also Pierce, Factors an Agency Can Consider, supra note 1 , at 82 (distinguishing between mandatory statutes requiring an agency take a particular action under certain circumstances, where existing doctrine discourages agency consideration of extrastatutory political factors, and more permissive delegations of authority where the relevant statutes only specify that an agency "may" take the action at issue based on consideration of specified factors); Watts, Proposing a Place, supra note 14, at 46-47.

29. See Watts, Proposing a Place, supra note 15 (encouraging judicial acceptance of express and transparent political involvement even as a decisive factor in an agency determination but discouraging the opposite).

30. See United States v. Mead Corp., 533 U.S. 218, 229 (2001). 
of either political accountability or technocracy and professional expertise dictate the doctrinal implications of any particular approach.

Roughly, both scholarship and jurisprudence on the factors that an agency may consider when implementing a statutory authorization can be divided into the three following categories defined by each approach's implications for judicial review: (1) highly deferential or even nonreview espoused by unitary executive theorists, ${ }^{31}$ (2) demanding review that views those considerations contained in any statute authorizing agency action as the exclusive grounds for any agency decision, ${ }^{32}$ and (3) varying review contingent upon different metrics of congressional intent, such as the relative independence of the agency receiving the authorizing delegation, ${ }^{33}$ or whether the agency implements in the appropriate manner its interpretation of the ambiguous factors Congress authorized that agency to consider. ${ }^{34}$ This Article will consider all three approaches, as all three find at least partial expression throughout administrative law. The contingent approaches prescribing varying levels of review warrant and receive the most attention both because the contingent approaches best encapsulate existing doctrine, and because they provide the best opportunity to accommodate both concerns for technocracy and political accountability.

First, Section II.A will survey unitary executive theory, which largely favors a more deferential judicial review of administration. The unitary executive argument holds that courts should permit an agency to consider any factors the executive directs that agency to consider in the implementation of its statutorily authorized delegation. ${ }^{35}$ Prudentially, unitary executive theorists argue that the president provides the most effective mechanism for politically accountable administration. ${ }^{36}$ While unitary executive theorists may maintain that presidential control enhances administrative expertise, perhaps with claims that Congress and line-item agencies are more susceptible to regulatory-capture than is the President as the only politician with a truly national constituency, ${ }^{37}$ administrative expertise is undeniably of secondary import relative to the constitutional considerations that mandate presidential direction of administration, or so the unitary executive argument contends. Section

\footnotetext{
31. See infra Section II.A.

32. See infra Section II.B.

33. See infra Section III.C.

34. See infra Section III.B.

35. See infra Section II.A.

36. See infra Section II.A.

37. Kagan, supra note 10, at 2339.
} 
II.A addresses this framework for judicial review in a limited manner because, regardless of the unitary executive theory's interpretive power as a construction of the Constitution or normative power as a prescription for the ideal federal government, the theory remains disconnected and indeed incompatible with large swaths of existing administrative law. ${ }^{38}$

Second, addressed in Section II.B, is an equally uncompromising position, albeit one that displaces presidential supremacy with congressional supremacy in advocating for a rigorous and searching judicial review of administration that would preclude an agency from considering any factors but those that Congress expressly authorized the agency to consider in the relevant delegating statute. ${ }^{39}$ Proponents of such an approach argue that agencies are at their most effective when unencumbered by political control, and able to pursue technocratic outcomes that best fulfill their statutory mandate. ${ }^{40}$ On the other hand, critics of such an approach argue it leads to regulatory ossification, which many commentators claim has reached unsustainable levels under State Farm review, ${ }^{41}$ an ostensibly more forgiving standard of review. ${ }^{42}$ Indeed, as with the unitary executive approach, this irrebuttable

38. Part II addresses this in greater detail, but as an initial matter, it is extremely difficult to reconcile Humphrey's Ex'r v. United States, 295 U.S. 602 (1935) (holding constitutional independent agencies insulated from presidential control removal power) with the unitary executive theory. Even more difficult for proponents of the unitary executive to accommodate in an account that seeks to describe existing doctrine is Morrison v. Olson, 487 U.S. 654 (1988) (upholding the constitutionality of a special prosecutor, removable only for cause, tasked with investigating and prosecuting government officials for certain violations of federal law). Further, given the nature of the unitary executive theorists' claims - specifically, that their interpretation is constitutionally mandated - the approach's merit seems far more likely to hinge upon broader questions of constitutional interpretation than on the theory's ability to explain the far narrower domain of judicial review of administrative rulemaking.

39. Jack M. Beermann, The Turn Toward Congress in Administrative Law, 89 B.U. L. REV. 727, 740 (2009) [Beermann, The Turn Toward] (reading Massachusetts v. EPA to support "the more general principle that... when an agency decides whether to take even preliminary steps in the regulatory process that might lead to rulemaking, it must consider Congress's factors rather than the agency's or the administration's preferred factors."). Beermann cites Deborah C. Fliegelman, Comment, The FDA and RU486: Are Politics Compatible with the FDA's Mandate of Protecting Public Health and Safety?, 66 TEMP. L. REv. 143, 152 (1993). See also Heinzerling, supra note 21, at 965-68 (noting the impermissibility of the FDA's efforts to justify age restrictions on "Plan B" medication by reference to a risk the authorizing statute did not permit the FDA to consider, specifically tradeoffs between "Plan B" and other forms of contraception).

40. See infra Part III.

41. See, e.g., Stephen Breyer, Breaking the Vicious Circle: Toward EFfective Risk REGULATION (1993).

42. State Farm provides a less rigorous review, requiring the reviewing court to invalidate only those agency actions premised upon factors that Congress did not intend the agency to consider. See infra Section III.A. Nothing about the invocation of congressional intent necessarily limits agencies to those express factors contained in the statute. See, e.g., MASHAW \& HARFST, supra note 1 , at 214 . 
presumption that Congress intended an agency to consider only those factors expressly contained in the delegating statute appears incompatible with modern doctrines of judicial review. In particular, this irrebuttable presumption cannot accommodate Chevron deference, ${ }^{43}$ which unquestionably applies to at least some instances in which agencies interpret their authorizing statutes to derive the factors that Congress intended that agency to consider in implementing that very statute. ${ }^{44}$

Third, addressed in Section II.C, are the contingent approaches to judicial determinations of the factors that an agency may consider in making any particular determination, which evaluate congressional intent as dispositive in determining what factors an agency may or may not consider when exercising delegated authority. While both unitary executive theorists and proponents of an irrebuttable and preclusive interpretive presumption require universal deference regimes-whether highly deferential or uncompromisingly scrutinizing-the contingent approaches advocate differential deference regimes. Proponents of these contingent approaches, which include all members of the current Supreme Court ${ }^{45}$ with the possible exception of Justices Thomas ${ }^{46}$ and Gorsuch, ${ }^{47}$ argue that: (1) courts should not uphold agency determinations reached with or justified by considerations that Congress precluded the agency from considering, and (2) Congress did not intend an agency to neglect a relevant factor just because Congress did not expressly reference that relevant factor in the agency's authorizing statute. $^{48}$ Advocates of this contingent approach have pursued, with

\footnotetext{
43. See infra Section III.A.

44. See generally Adrian Vermeule, LaW's AbNegation: From LaW's Empire to the ADMINISTRATIVE STATE 200-01 (2017).

45. Including Justice Kavanaugh. See Brett M. Kavanaugh, Fixing Statutory Interpretation, Judging Statutes, 129 HARV. L. REV. 2118, 2152 (2016) (“Chevron makes a lot of sense in certain circumstances. It affords agencies discretion over how to exercise authority delegated to them by Congress. For example, Congress might assign an agency to issue rules to prevent companies from dumping 'unreasonable' levels of certain pollutants. In such a case, what rises to the level of 'unreasonable' is a policy decision. So, courts should be leery of second-guessing that decision. The theory is that Congress delegates the decision to an executive branch agency that makes the policy decision, and that the courts should stay out of it for the most part. That all makes a great deal of sense and, in some ways, represents the proper conjunction of the Chevron and State Farm doctrines.").

46. See Michigan v. EPA, 135 S. Ct. 2699, 2712 (2015) (Thomas, J., concurring) (writing separately to "note that [the EPA's] request for deference raises serious questions about the constitutionality of our broader practice of deferring to agency interpretations of federal statutes").

47. See Gutierrez-Brizuela v. Lynch, 834 F.3d 1142, 1149-58 (10th Cir. 2016) (Gorsuch, J., concurring).

48. See, e.g., MASHAW \& HARFST, supra note 1, at 215. ("This agency, any agency, should always read between the lines of its statute an implicit qualification of the form: 'Don't forget that this statute does not exhaust our vision of the good life or the good society. Remember that we have
} 
varying degrees of success, the establishment of different interpretive presumptions to approximate congressional intent regarding the allocation of interpretive authority between courts and agencies to derive extra-statutory reasons sufficient to support an administrative outcome. Disputes over the scope and precise formulation of these presumptions account for much of the doctrinal and academic disagreement in existing administrative law. This Article centers upon two of these interpretive presumptions. $^{49}$

This Article argues that Chevron ${ }^{50}$ deference is best understood as one such contingent approach to the question of whether courts or agencies should derive the extra-statutory factors an agency may rely upon in support of any administrative outcome. Because an agency necessarily construes a statute each time that agency determines the factors Congress authorized the agency to consider when arriving at an administrative outcome, courts must defer to that determination so long as the agency acts "with the force of the law" ambiguous. ${ }^{52}$ Chevron deference, then, seeks to create a presumption of judicial deference towards agency interpretations of the statutes specifying the factors that agency may consider contingent upon the type of action the agency employs to implement the relevant statutory construction. $^{53}$ While such deference unquestionably applies to a wider range of agency legal determinations than the statutory construction required to derive the factors that an agency may or must consider before acting, all of an agency's legal resolutions of ambiguous statutory mandates necessarily begin with a construction of the relevant statute to derive the factors that agency believes it is required or permitted to

other goals and other purposes that will sometimes conflict with the goals and purposes of this statute. If we forgot to mention all those potential conflicting purposes in your instructions, take note of them anyway. For heaven's sake, be reasonable."'); Watts, Proposing a Place, supra note 15 , at 52 .

49. See infra Part III. While alternative presumptions exist, most are divorced from congressional intent and instead derive support from purely prudential considerations about the efficacy or accountability of administration. See, e.g., Catherine M. Sharkey, State Farm "With Teeth": Heightened Judicial Review in the Absence of Executive Oversight, 89 N.Y.U.L. REV. 1589, 1590 (2014) (arguing that the presence of "meaningful executive oversight, premised on a reasoned decision-making basis" in a particular administrative process should receive heightened judicial deference without deriving any support from claims about congressional intent).

50. Chevron U.S.A., Inc. v. Nat. Res. Def. Council, Inc., 467 U.S. 837 (1984).

51. United States v. Mead Corp., 533 U.S. 218 (2001) (granting Chevron deference only when agencies have exercised delegated power to act with the force of law). Christensen v. Harris Cty., 529 U.S. 576, 587 (2000), excluded interpretive regulations from Chevron's domain, requiring agencies issue legislative regulations to receive Chevron deference when promulgating regulations.

52. Chevron, 467 U.S. at 843.

53. Gersen \& Vermeule, supra note 6, at 1372. 
consider.

An alternative contingent approach argues for a presumption of judicial deference contingent upon the type of agency implementing the

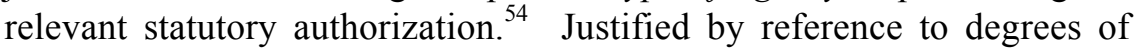
presidential direction, this interpretive presumption distinguishes between statutory delegations to executive agencies as permitting that agency implementing the statute to consider or rely upon presidential direction, and statutory delegations to independent ${ }^{55}$ agencies as precluding that agency from considering presidential direction. ${ }^{56}$ Reframed as a presumption about the types of agencies that should receive deference when interpreting statutes to derive the factors those agencies may consider when implementing their statutory mandate, this Article argues that courts should grant greater deference to executive agencies' derivation of extra-statutory reasons for an administrative outcome, than to independent agencies' derivation of extra-statutory reasons for an administrative outcome. In doctrinal terms, this interpretive presumption implies that courts should grant Chevron deference to an executive agency's statutory construction of the factors that agency may or must consider before acting, while granting Skidmore deference $^{57}$ to an independent agency's statutory construction of the factors that agency may or must consider before acting.

The Supreme Court's decision in FCC v. Fox Television Stations, Inc. ${ }^{58}$ announced an even split on a closely-related question. ${ }^{59}$ In Fox, the Court reviewed under the arbitrary and capricious standard whether the Federal Communications Commission appropriately formulated a new policy on sanctionable ${ }^{60}$ language issued in an order that eliminated

54. First proposed by Kagan in Presidential Administration, supra note 10, but seemingly quickly abandoned. See David J. Barron \& Elena Kagan, Chevron's Nondelegation Doctrine, 2001 SUP. CT. REV. 201 (2001) (arguing Chevron deference should apply only to those interpretations made by the individual to whom Congress delegated decision-making authority).

55. See infra Section III.C.1 for a discussion of the definition of an independent agency in this context.

56. Kagan, supra note 10, at 2372.

57. Skidmore v. Swift \& Co., 323 U.S. 134, 140 (1944) (holding an administrative agency's interpretation warrants deference only insofar as courts find that agency's interpretation persuasive).

58. 556 U.S. $502(2009)$.

59. The relevant piece of Justice Scalia's majority opinion, arguing against heightened judicial review of independent agencies to ensure the apolitical nature of their determinations, commanded only three further votes. Id. at 525. Similarly, Justice Breyer's dissent arguing for heightened judicial scrutiny of decisions made by independent agencies commanded only three additional votes. Justice Kennedy declined to address the question, concurring only with Justice Scalia's result. Id. at 548 (Breyer, J., dissenting).

60. Id. at 503 ("Actionably indecent"). 
the FCC's prior safe-harbor for non-repeating expletives. ${ }^{61}$ Justice Breyer, writing in a dissent joined by three other justices, formulated the question as whether the FCC's "comparative freedom from ballot-box control [as an independent agency] makes it all the more important that courts review its decisionmaking to assure compliance with applicable provisions of the law ...." 62 The question presented in Fox did not require the Court to go so far as to reconsider the controlling doctrinal regime for evaluating an agency's statutory construction of the factors it may and must consider when acting. ${ }^{63}$ This Article will nonetheless address the concerns for political accountability and technocracy animating the Fox decision to argue in favor of a new regime of judicial deference contingent upon the type of agency receiving the congressional delegation, rather than the type of action with which the agency implements its statutory interpretation.

Part III will argue that, while the recipient agency's independence is by no means a perfect mechanism for deriving congressional intent concerning the level of deference with which courts should evaluate that agency's derivation of the factors that the delegating statute permits the recipient agency to consider, ${ }^{64}$ it is a comparatively superior indication of congressional intent that most effectively balances concerns for technocracy with concerns for political accountability. First, while both courts and commentators recognize the fictitious nature of the notion of congressional intent upon which the Chevron presumption rests, ${ }^{65}$ Congress actually considers the independence from presidential direction enjoyed by an agency receiving a particular delegation. ${ }^{66}$ The independence of the agency receiving the delegation, then, provides a stronger indication of congressional intent regarding that agency's leeway to derive factors to consider from the relevant statute than the

\footnotetext{
61. Id.

62. Id. at 547 (Breyer, J., dissenting) (emphasis added). Justice Scalia, writing in a portion of the majority opinion also joined by only three other justices presented the question slightly differently: whether 'the FCC's status as an 'independent' agency sheltered from political oversight requires courts to be 'all the more' vigilant in ensuring 'that major policy decisions be based upon articulable reasons." Id. at 523 (majority opinion). For Justice Scalia, this framing question is significant for the outcome, and may well be dispositive. Id. ("Justice Breyer purports to "begin with applicable law,' but in fact begins by stacking the deck." (citation omitted)).

63. Indeed, Chevron was not cited once in the opinions, as the FCC's statutory interpretation was not challenged.

64. See infra Section III.C.

65. Cass R. Sunstein, Chevron Step Zero, 92 VA. L. Rev. 187, 192 (2006).

66. See generally Kirti Datla \& Richard L. Revesz, Deconstructing Independent Agencies (and Executive Agencies) 98 CORNELl L. REV. 769 (2013); Rachel E. Barkow, Insulating Agencies: Avoiding Capture through Institutional Design, 89 TEX. L. REV. 15 (2010).
} 
mechanism by which an agency implements a particular statutory interpretation. ${ }^{67}$ Second, insofar as an agency's independence presents a meaningful impediment to presidential control of administrative processes ${ }^{68}$ concerns for political accountability should direct courts reviewing independent agency action to more closely ensure agency compliance with the only remaining source of political control: the authorizing statute. ${ }^{69}$ Third, concerns for administrative expertise also counsel in favor of heightened judicial review of an independent agency's compliance with its statutory mandate to ensure the agency's decision does not reduce the technocratic deliberation authorized by statute to an empty exercise in justifying politically-dictated outcomes. ${ }^{70}$ Finally, deference contingent upon the type of agency receiving the congressional delegation rather than the type of action with which the agency implements its statutory interpretation creates a clearer brightline that resolves the intense ambiguity shrouding the distinction between agency actions with and without the force of law at the heart of contemporary disputes about Chevron's domain. ${ }^{71}$

That courts have applied Chevron deference to an agency's statutory derivations of the permissible factors that any agency may consider when

67. See infra Section III.C.

68. Id.

69. FCC v. Fox Television Stations, Inc., 556 U.S. 502, 547 (2009) (Breyer, J. dissenting); Randolph J. May, Defining Deference Down: Independent Agencies and Chevron Deference, 58 Admin. L. ReV. 429 (2006) [hereinafter May, Defining Deference Down]; Randolph J. May, Defining Deference Down, Again: Independent Agencies, Chevron Deference, and Fox, 62 ADMIN. L. REV. 433 (2010) [hereinafter May, Defining Deference Down, Again]. However, some proponents of political involvement in the administrative process argue the benefits of presidential administration should subsume concerns for fidelity to congressional delegations. Freeman \& Vermeule, supra note 17, at 23. Only if successful would presidential administration of the independent agencies implicate judicial review; accordingly, until the Executive has overcome agency independence in form or function, arguments for the presidential administration of independent agencies seek changes in presidential rather than judicial behavior. While the President has enjoyed recent success in exerting some control over independent agencies through statutorily authorized channels of influence - predominantly, appointment power-entrenched conventions that insulate independent agencies from politics even absent formal barriers should prove insurmountable for proponents of presidential administration absent a significant turn towards the unitary executive model. Adrian Vermeule, Conventions of Agency Independence, 113 COLUM. L. REV. 1163, 121314 (2013).

70. Freeman \& Vermeule, supra note 17, at 78 (describing the court's response to concerns of political involvement as "forc[ing] EPA to defend its second-order decision solely by reference to narrower technocratic factors.”); Bressman, Beyond Accountability, supra note 19, at 789.

71. Sunstein, supra note 65, at 221 (describing “a kind of Step Zero chaos"); Lisa Schultz Bressman, How Mead Has Muddled Judicial Review of Agency Action, 58 VAND. L. REV. 1443 (2005) [hereinafter Bressman, How Mead Has Muddled] (arguing that "[y]ears have passed since Mead was decided, and we still lack a clear answer to the question when an agency is entitled to Chevron deference for procedures other than notice-and-comment rulemaking or formal adjudication"). 
implementing the mandate or authorization, ${ }^{72}$ of course, does not make Chevron deference about statutory derivations of the permissible factors an agency may consider when acting. Despite appearing in many forms, an agency's statutory interpretations are, first and foremost, interpretations of the factors that Congress has authorized agencies to consider when implementing statutory authorizations or mandates. ${ }^{73}$ Professor Pierce explains:

There is only one link between [the] policymaking process and the process of statutory interpretation. In the course of explaining why it made the decisions it made, the agency must refer to decisional factors that the underlying statute makes permissible. For that purpose, the agency must engage in statutory interpretation to the extent necessary to explain why it believes that a decisional factor it applies is statutorily permissible.

In other words, the relevance of Chevron deference to agency interpretations of the statutorily permissible factors that an agency may consider when implementing its statutory mandate is the mechanism by which Chevron realizes its "imperialistic aspirations,"75 and implicates

72. Bluestone Energy Design, Inc. v. F.E.R.C., 74 F.3d 1288, 1295 (D.C. Cir. 1996) ("Because the Federal Power Act does not directly address the propriety of considering staff time and resources, we turn to the second step of Chevron, testing for reasonableness the Commission's view that use of staff time and resources is relevant to the statutory factors."); Pension Benefit Guar. Corp. v. LTV Corp., 496 U.S. 633, 647-52 (1990) (granting Chevron deference to the Pension Benefit Guaranty Corporation's interpretation of an ERISA section to permit the PBGC to make a particular decision based upon a consideration not expressly referenced in the statute). In $L T V$, the Court first held that the statute "does not evince a clear congressional intent to deprive the PBGC of the ability to base restoration decisions on the existence of follow-on plans" because a failure to consider follow-on plans "may tend to frustrate one of the objectives of ERISA that the PBGC is supposed to accomplish ...." Id. at 648. The Court permitted the agency to consider such factors, even though "[o]n their face... none of [the] statutorily identified purposes has anything to say about the precise question at issue - the use of follow-on plans as a basis for restoration decisions." Id. at 649.

73. Part III provides a doctrinal summary of Chevron deference since its inception to demonstrate that Chevron deference is best understood as deference towards agencies' statutory constructions of permissible factors for consideration.

74. Pierce, How Agencies Should Give Meaning, supra note 1, at 204. Professor Pierce may have overstated his point, however; in Chevron itself, for example, EPA's statutory interpretation was the policymaking. While agency policymaking no doubt requires the statutory derivation of permissible decisional factors, that interpretive process is not necessarily the only way in which agency policymaking intersects with statutory interpretation. Nonetheless, Pierce's claim retains its accuracy in practice so long as it is possible to reduce all of an agency's interpretive processes to a derivation of statutorily permissible factors. See infra Section III.A argues this is the case because Chevron Step Two, which assesses the reasonability of an agency's interpretation, amounts to an assessment of the agency's statutory derivation of the factors upon which it can rely in support of a particular administrative outcome. In other words, judicial review of the reasonability of an agency's interpretation is, at its core, judicial review of the reasonability of what the agency determines the aims of the statute or regulatory scheme to be.

75. Sunstein, supra note 65 , at 189. 
all judicial review of agency action.

This Article concludes with an argument for a reformulated Chevron Step Zero, the force of which becomes apparent by reframing the doctrinal quarrel between proponents of technocracy and proponents of presidential administration as a dispute about the deference with which a court should review an agency's statutory construction of the factors that Congress intended that agency to consider when acting to implement any given mandate. While scholarship generally asks whether courts should permit agencies to provide political justifications for agency actions, the framing adopted in this Article more accurately depicts the context in which that question indirectly arises: review of an agency's determinations of permissible factors for consideration. This Article's contributions are twofold. First, this Article provides a more precise account of the existing regime of judicial review that explains and reconciles the two most prominent regimes of judicial review-State Farm and Chevron-without equating distinct standards of review. Second, this Article argues that the more precise account of existing doctrine offered within decisively undermines the strength of existing justifications for Chevron deference contingent upon the type of action with which an agency implements its statutory authorization, rather than the type of agency that receives a particular authorization, suggesting the desirability of a reformulated Chevron Step Zero that grants deference only to the relevant statutory interpretations of executive agencies. ${ }^{76}$

\section{CONGRESSIONAL AND EXECUTIVE SUPREMACY: THEORETICAL JUSTIFICATIONS}

This Part surveys the theoretical justifications for and doctrinal implications of the unitary executive theory and a Congress-centric theory of administration. While the former proscribes near-absolute judicial deference to an agency's reliance upon extra-statutory considerations, the latter proscribes a scrutinizing judicial review of administrative actions to ensure agencies considered only those factors that the relevant authorizing statute expressly permitted the agency to consider. Despite finding limited expression in a judiciary unwilling to

\footnotetext{
76. Numerous reformulations of Chevron Step Zero have been proposed, ranging from a "general presumption of authority in agencies to resolve ambiguity in the statutes they have been authorized to enforce", United States v. Mead, 533 U.S. 218, 239 (2001) (Scalia, J., dissenting), to attempts "to distinguish among exercises of [] authority based on the identity of the final agency decision maker and then to reward, through more deferential judicial review, interpretations offered by more responsible officials." Barron \& Kagan, supra note 54, at 202.
} 
commit to either absolute, these two mostly-hypothetical regimes of judicial review remain the most influential schemes in competition with the contingent approaches that most closely track existing doctrine. ${ }^{77}$ These two understandings of the role of judicial review in the administrative state diverge from contingent approaches addressed later in two fundamental ways: (1) both reject varying degrees of deference, preferring courts to adopt either highly deferential or carefully scrutinizing review of all agency actions; and (2) both reject determinations of implied congressional intent, ${ }^{78}$ focusing instead on either the express factors that the statute specifies an agency may consider when implementing the statute ${ }^{79}$ or the constitution's exclusive grant of the take care power to the President. ${ }^{80}$ This unwillingness to accommodate considerations of congressional intent and disregard for the ascendant case-by-case deference regime ${ }^{81}$ provides one compelling

77. See infra Section III.A.

78. While the statute's text is no doubt central to determinations of congressional intent, to utilize text exclusively is in effect to deny intent's relevance. See John F. Manning, Textualism and Legislative Intent, 91 VA. L. REV. 419 (2005); J.R. DeShazo \& Jody Freeman, The Congressional Competition to Control Delegated Power, 81 TEX. L. ReV. 1443, 1461 (2003). In this Article, textualism serves as an analogy, not a categorization of attempts to limit agency considerations to those factors expressly contained in the authorizing or delegating statute. Indeed, the most prominent self-proclaimed textualist-Justice Scalia-explicitly dissented against such logic in Massachusetts v. EPA, 549 U.S. 497, 552 (2007), writing:

Thus, the various "policy" rationales that the Court criticizes are not "divorced from the statutory text," except in the sense that the statutory text is silent, as texts are often silent about permissible reasons for the exercise of agency discretion. The reasons EPA gave are surely considerations executive agencies regularly take into account (and ought to take into account) when deciding whether to consider entering a new field. (citations omitted).

How strict textualists who nonetheless favor expansive executive powers of interpretation, such as the late Justice Scalia, may reconcile their willingness to accept agency's consideration of extrastatutory factors with statutory textualism raises a number of interesting questions, here unanswered.

79. Beermann, The Turn Toward, supra note 39, at 740-41. Professor Beermann's The Turn Toward Congress in Administrative Law ultimately defends a more moderate approach:

The President's policies should influence agencies both because the President is the constitutional locus of executive power and because of the democratic value of agency accountability through the President. The location of executive power in the President does not, however, tell us how much influence Congress should have over the execution of the law .... There is no sensible view of separation of powers that would favor impeding judicial review's ability to aid Congress in keeping agencies in line with legislatively express priorities.

$I d$. at 742-43. Beermann's position is thus consistent with the reading of recent Supreme Court jurisprudence infra Section III.A, albeit without articulating a presumption for the judicial review of the permissibility of agencies considering extra-statutory factors.

80. Steven G. Calabresi \& Saikrishna B. Prakash, The President's Power to Execute the Laws, 104 YALE L.J. 541, 664 (1994) ("[T]he Constitution grants the President the authority to superintend the administration of federal law. There are no caveats. There are no exceptions.").

81. See infra Section III.B. 
explanation for these approaches doctrinal obsolescence, as congressional intent has taken on increasing import to the Court's justification for deference to administration. ${ }^{82}$

The following subsections examine first the unitary executive model and its attendant regime of deferential judicial review of administration and, second, the statutory supremacy model and its attendant regime of "harder" look review. Because each regime amounts to a totalizing embrace of either congressional or executive supremacy, the justifications presented by proponents of either regime provide a useful summary of the considerations for political accountability and technocracy, both of which the more accommodating regimes of judicial review will attempt to express. ${ }^{83}$ While the contingent approaches seek to balance a court's evaluation of congressional intent with concerns for an agency's political accountability and professional expertise, the unitary executive and statutory-supremacy models rely upon external considerations - most prominently, separation of power theories embedded in the constitution - to adopt totalizing modes of judicial review with little regard for prudential outcomes.

\section{A. Unitary Executive Theorists and Congressional Irrelevance}

Since at least the Reagan administration, concerns for administration's lack of democratic accountability have justified enhanced presidential control of administration. ${ }^{84}$ In its earliest iteration, presidential administration adopted its most uncompromising form: the unitary executive strand of political administration. ${ }^{85}$ The unitary executive model claims that presidential control of administration is not only permissible, but constitutionally compelled. ${ }^{86}$ The "classic theory of the unitary executive" posits three powers relevant to administration as fundamental and exclusively committed to the executive by the constitution: "the president's power of removal, the president's power to direct subordinate executive officials, and the president's power to

\footnotetext{
82. $I d$.

83. Infra Part III.

84. Kagan, supra note 10, at 2277.

85. Mark Tushnet, A Political Perspective on the Theory of the Unitary Executive, 12 U. PA. J. CONST. L. 313, 315-18 (2010).

86. Yoo, Calabresi \& Colangelo, supra note 14 at 607; STEPHEN G. CALABresi \& Christopher S. Yoo, The Unitary Executive: Presidential Power From Washington to Bush 14-15 (2008); David E. Lewis, Presidents ANd the Politics of Agency Design: POlitical Insulation in the United States Government Bureaucracy, 1946-1977, 24 (2003).
} 
nullify or veto subordinate executive officials' exercise of discretionary executive power." 87

In the context of judicial review of an agency's justifications for selecting a particular course of action, all formulations of the unitary executive model of presidential administration ${ }^{88}$ argue that courts should not dictate those factors - whether political or otherwise - that an agency may consider or rely upon when implementing a statutory authorization. ${ }^{89}$ By positing agencies as agents of the executive meant to assist in the implementation of the law, ${ }^{90}$ the unitary executive model requires that the president possesses the unconstrained constitutional authority to control, even by removal, all executive officers. ${ }^{91}$

Insofar as the unitary executive theory views the congressionally imposed restraints on the executive's removal power upheld in Humphrey's Executor v. United States ${ }^{92}$ as unconstitutional, ${ }^{93}$ the theory appears disconnected from the judicial review of administration in practice regardless of the theory's force as a normative account of Article

87. CALABRESI \& YoO, supra note 86 , at 14.

88. Tushnet, supra note 85 , notes that there exist numerous manifestations of the unitary executive model, with ideological commitments varying in strength. Even under what Tushnet calls the "weak theory" of the unitary executive, however,

the President has the power to provide policy direction to officers of the United States, to remove from their positions any such officers who refuse to comply with the President's policy directions, and (perhaps) to implement presidentially determined policy directly by transmitting policy directives to employees who are obliged to carry them out or themselves face dismissal.

Id. at 315 . Because the powers necessary for presidential administration-unconstrained removal power and presidential direction-reside even in the weakest formulation of the unitary executive theory, this Article need not address the theory's stronger formulations in depth.

89. This is not to say that statutory language is irrelevant to judicial review of administration under the unitary executive model; even courts subscribing to the unitary executive model would be unlikely to uphold an EPA emissions standard justified by reference to economic cost when the statute expressly precluded the agency from considering economic costs. Rather, so long as the statute did not dictate a particular outcome, the President's preferences could provide acceptable justifications for an administrative outcome even if that outcome were not supported by expert analysis. Professor Edley usefully distinguishes between "politics-as-preference", where courts recognize that "[t]he preferences of the decision maker cannot be eliminated from agency choices", and the "politics-as-market" approach that grants dispositive status to political preferences even absent expert support. Christopher F. EdLEY, JR., ADMINISTRATIVE LAW: RethinKING JUdiCIAL CONTROL OF BUREAUCRACY 184 (1990).

90. Calabresi \& Prakash, supra note 80, at 597.

91. CALABRESI \& YoO, supra note 86 , at 4 .

92. 295 U.S. 602 (1935). Even more difficult for proponents of the unitary executive to accommodate in an account that seeks to describe existing doctrine is Morrison v. Olson, 487 U.S. 654 (1988) (upholding the constitutionality of a special prosecutor, removable only for cause, tasked with investigating and prosecuting government officials for certain violations of federal law).

93. CALABRESI \& YoO, supra note 86 , at 4 . 
II. ${ }^{94}$ Additionally, because any implications for judicial review of administration are of secondary importance to proponents of the unitary executive model, the model's merit is unlikely to be resolved anywhere but the domain of constitutional interpretation upon which it relies.

A more nuanced account of the unitary executive that seeks to accommodate the court's holding in Humphrey's Executor argues that even if the executive lacks the constitutional authority to remove all officers without cause, the executive "may withdraw his consent to the exercise of executive authority in particular instances" and thereby "totally retract a [noncompliant officer's] executive power." 95 However, this understanding of removal power fails to provide an affirmative justification for the requirement that agencies consider extra-statutory factors, specifically presidential direction. While the more forceful iterations of the unitary executive theory justify presidential administration as constitutionally mandated, this weaker formulation only presents presidential administration as constitutionally permissible, relying upon the prudential claims surveyed below to make the affirmative case for presidential control of administration.

Accordingly, both unitary executive theorists and proponents of presidential administration argue that even if the constitution does not mandate presidential control, such control is both normatively desirable ${ }^{96}$ and an accurate description of administrative decision-making since the Reagan administration. ${ }^{97}$ On the normative level, proponents of enhanced presidential involvement in administrative rulemaking argue that such control legitimates administration through the infusion of political accountability, provides regulatory impetus in an era characterized by ossification, and counters particularized interests that otherwise wield disproportionate influence. ${ }^{98}$

94. See, e.g., Kagan, supra note 10, at 2326 (arguing that "the cases sustaining restrictions on the President's removal authority, whether or not justified, are almost certain to remain the law ... as a result, any serious attempt to engage the actual practice of presidential-agency relations must incorporate these holdings and their broader implications as part of its framework").

95. Calabresi \& Saikrishna, supra note 80, at 598-99.

96. Kagan's Presidential Administration, supra note 10, presents the most prominent formulation of this model of presidential administration.

97. Then-Professor Barron's recent history of presidential administration, supra note 25, at 1097, provides compelling support for the descriptive components of Kagan's claims. But see Edward H. Stiglitz, Unitary Innovations and Political Accountability, 99 CORNELL L. REV. 1133 (2014).

98. See, e.g., Kagan, supra note 10; Watts, Proposing a Place, supra note 15; Lawrence Lessig \& Cass R. Sunstein, The President and the Administration, 94 Colum. L. Rev. 1, 4 (1994) (arguing strong presidential control of administration ensures political accountability the avoidance of factionalism); Kathryn A. Watts, Controlling Presidential Control, 114 MICH. L. REV. 683, 724 26 (2016) [hereinafter Watts, Controlling Presidential Control]; EDLEY, supra note 89, at 184-99. 
First, presidential direction legitimates the administrative state by introducing political accountability. ${ }^{99}$ As the only elected official with a national constituency, ${ }^{100}$ the president "establishes an electoral link between the public and the bureaucracy, increasing the latter's responsiveness to the former." ${ }^{101}$ Moreover, unlike other intrusions into administrative processes, presidential control creates a direct line of responsibility comprehensible to the public, thereby increasing that "fundamental precondition of accountability in administration": bureaucratic transparency. ${ }^{102}$ Even if presidential involvement imperfectly enhances the accountability of administration, ${ }^{103}$ the claim that presidential involvement is a comparatively more effective instrument of accountability cannot be easily refuted. ${ }^{104}$

Second, proponents of political control argue that courts' acceptance of presidential involvement in administration reduces regulatory ossification, a claim advanced in two forms. The weaker formulation argues that judicial acceptance of political justifications as sufficient or even supporting bases for agency action provides another mechanism for upholding agency determinations subject to hard look review because an increase in the availability of justifications available for a particular agency action will decrease the likelihood that agencies decline to act out of fear of judicial review. ${ }^{105}$ The stronger formulation contends presidential direction and control imputes "energy" into administration, defined by Kagan as "the imposition of a coherent regulatory philosophy across a range of fields to produce novel regulatory (or for that matter,

99. Watts, Controlling Presidential Control, supra note 98, at 724-25; Mark Seidenfeld, The Role of Politics in a Deliberative Model of the Administrative State, 81 GEO. WASH. L. REV. 1397, 1457 (2013) (arguing that "for rulemaking in which the President personally dictates his preference for an outcome at the end of the deliberative process, presidential preference has greater legitimacy than the independent choice of the agency."). But see Glen Staszewski, Political Reasons, Deliberative Democracy, and Administrative Law, 97 IOWA L. REV. 849, 852 (2012).

100. Kagan, supra note 10, at 2336.

101. Id. at 2332 .

102. Id. Kagan does acknowledge, however, that the strength of these claims varies greatly depending upon the President's willingness to take responsibility, and thus blame or credit, for administrative actions. Kagan notes that Reagan "usually tried... to veil his and his staff's influence over administration", while Clinton claimed "authority to make discretionary decisions delegated to the agencies," exercised "that authority in public directives," and spoke of "agency actions as his own." Id. at 2333.

103. It is a dubious proposition that a president's electoral success hinges upon any particular administrative decision in which he may involve himself, for example.

104. Kagan, supra note 10, at 2334.

105. Watts, Proposing a Place, supra note 15, at 41-42 ("If agencies were allowed to justify their decisions in both technocratic and political terms, then these sorts of 'ossification' charges likely would be softened because courts would have yet another reason to uphold agency decisions."). 
deregulatory) policies."106 According to Kagan, executive "energy" alleviated regulatory ossification in both the Clinton and Reagan administrations. ${ }^{107}$ Executive directives and the refashioning of administrative priorities that occurs with changes in administration thus create the impetus for regulatory development. ${ }^{108}$

Third, proponents of presidential administration argue political control enhances rather than undermines bureaucratic expertise. Building upon the aforementioned "energy" claims, proponents argue that presidential control coheres administration across regulatory schemes in agency rulemaking. ${ }^{109}$ Where rulemaking conducted by agencies unaccountable to the president may instead prioritize the narrow interests reflected in their constituencies, ${ }^{110}$ presidential involvement ensures that agencies consider the broader context in which regulation (or deregulation) occurs. Rather than heighten technocratic expertise, narrow mandates and narrower sets of considerations blind agencies to the bigger picture necessary for efficacious regulation, or so the presidentialists claim. ${ }^{111}$

Crucial to all three of these claims is the notion that no administrator can avoid political involvement in bureaucracy. ${ }^{112}$ Insofar as politics, defined by the prioritizing of particular values, is a necessary component of the rulemaking process, proponents of presidential administration argue that agencies will distort facts and science to align with embedded political goals even absent explicit presidential control. ${ }^{113}$ The removal of presidential control that reflects democratic input from the administrative rulemaking process will not render agency decisions less political, but rather force the political valuations underground. ${ }^{114}$ In this

106. Kagan, supra note 10 , at 2341 , argues that this is particularly true when administrative ossification reflects congressional partisan gridlock.

107. Id. at 2345 .

108. Id. at 2341 .

109. Id. at 2340 .

110. Whether special corporate or special "public" interests, the groups with the incentives to engage the regulatory process seldom reflect the national polity as a whole.

111. Vermeule, supra note 26, at 2480.

112. Watts, Controlling Presidential Control, supra note 98, at 724 (concluding that "it is futile to try to sanitize agency rulemaking of political influences" because, "[w]hen science and expertise alone cannot answer questions concerning how or when best to regulate, competing value-laden policy preferences necessarily and inevitably will come into play."); Mark Seidenfeld, The Irrelevance of Politics for Arbitrary and Capricious Review, 90 WASH. U. L. REV. 141, 197 (2012).

113. Watts, Proposing a Place, supra note 15, at 40.

114. EDLEY, supra note 89, at 188 ("In these circumstances, the remand justified through a scientific lens merely invites a subterfuge in the parading of expertise."); Watts, Proposing a Place, supra note 15. 
sense, technocracy and presidential administration remain compatible. Because rulemaking, and indeed almost all administrative processes, involve both factual and value judgments, technical expertise and politics necessarily coexist. To the extent that presidential control provides an express set of value priorities to structure the technical evaluations below, as proponents of presidential administration argue occurs, the two priorities may take on mutually reinforcing forms.

That each of these arguments for presidential direction of administration finds significant empirical and theoretical support, however, does not, in and of itself, provide sufficient justification to adopt even the weaker unitary executive model as a framework for the judicial (non)review of administration. As Part III demonstrates, various interpretive presumptions exist that, while owing significant ideological debt to the unitary executive theorists, ${ }^{115}$ need not embrace the theory in its entirety to promote presidential involvement in administration. Even the weaker formulation of the unitary executive theory's persuasiveness rests on other grounds, ${ }^{116}$ and the administrative implications remain secondary and disconnected from the existing state of the law. Indeed, while perhaps able to accommodate the court's decision in Humphrey's Executor that constitutionally validated the for cause removal requirements with which Congress insulates independent agencies, Morrison v. Olson's function usurpation test ${ }^{117}$ remains incompatible with even the weakest formulation of the unitary executive theory. ${ }^{118}$

\section{B. Statutory Supremacy and Presidential Irrelevance}

The statutory supremacy model dictates a model of judicial review of administration opposite to that dictated by the unitary executive model. ${ }^{119}$

115. It is for this reason that this Section surveys the normative arguments for presidential administration in such depth. Even if they prove insufficient to support the weight of the unitary executive theory in its entirety, these claims provide influential metrics for assessing the values promoted by judicial review of administration in its less absolute forms.

116. Originalist readings of the constitution, predominately.

117. Morrison v. Olson, 487 U.S. 654, 691 (1988) ("There is no real dispute that the functions performed by the independent counsel are 'executive' ....").

118. Steven G. Calabresi \& Christopher S. Yoo, Remove Morrison v. Olson, 62 VAND. L. REV. EN BANC 103, 119 (2009).

119. The phrase statutory supremacy intends to evoke-without incorporating - the concept of legislative supremacy in statutory interpretation, which places courts in a subordinate role to Congress in the interpretation of statutes so as to implement a particular notion of public policy. Daniel A. Farber, Statutory Interpretation and Legislative Supremacy, 78 GEO. L.J. 281 (1989). Here, statutory supremacy subjugates both agencies and courts to Congress in the implementation of a particular notion of public policy. 
The statutory supremacy approach counsels courts to review administration to restrict the factors agencies consider when implementing a statutory mandate or authorization to only those factors referenced in the relevant statute. This regime of judicial review premised upon statutory supremacy derives theoretical backing from two distinct, and perhaps contradictory, sources: technocracy and congressional control of administration. Both justifications, however, rest upon the assumption that agencies are more likely to consider either expertise-impeding or political extra-statutory factors than expertiseenhancing logically relevant extra-statutory factors that Congress failed to expressly include but which are consistent with congressional intent. ${ }^{120}$

First is a belief in technocracy; agencies permitted to consider or rely upon extra-statutory factors when implementing a statutory mandate will become too easily swayed from technically sound outcomes by the President's political priorities. ${ }^{121}$ Even if political priorities in administration are inevitable, expertise-forcing may effectively suppress agency reliance upon political pressure in the following ways: (1) if forced to justify decisions only with reference to expertise-related factors, agency officials "sufficiently concerned for the agency's reputation as an expert" might refrain from distorting technocratic decisions for fear of "incurring mockery and outrage from scientific and technocratic experts"; ${ }^{122}$ (2) "if the agency realizes that any first-order judgment it makes will alienate some constituency or other... then it may decide to let the scientific chips fall where they may, on the principle that one might as well be honest if dishonesty will not pay"; ${ }^{123}$ and (3) the threat of judicial review, even if not always effective at identifying dispositive political factors an agency considered, may at least deter agencies from trying in those instances where the science is clear. $^{124}$

Concerns for technocracy, however, need not lead to blanket prohibitions of agency reliance upon extra-statutory considerations of the kind contemplated by certain readings of the majority in Massachusetts

120. Freeman \& Vermeule, supra note 17, at 88-89.

121. This logic underpins the Supreme Court's decision in Massachusetts v. EPA. See generally Freeman \& Vermeule, supra note 17 , at 83.

122. Id. at 98 ("A person who is willing to refrain from pointing out that the emperor is wearing no clothes may balk at saying out loud that the clothes exist.").

123. Id. at 98.

124. Id. See also Heinzerling, supra note 21, at 971 (explaining the blatant scientific inaccuracies underpinning the FDA's justifications for age limits on access to "Plan B" undermined the FDA's ability to defend the administrative outcome it sought in court). 
v. $E P A .^{125}$ Even if one accepts that agency consideration of extrastatutory factors more often reflects political control than agency expertise, one need not accept that a prohibition on agency consideration of extra-statutory factors is superior to a prohibition on agency consideration of political pressure. ${ }^{126}$ In this way, then, the fate of the prudential justifications for statutory supremacy mirror the fate of prudential justifications for the unitary executive model: even if compelling, the justifications prove ill-fitting for the approach on behalf of which they are marshalled. Accordingly, statutory-supremacists must justify their desired regime of judicial review without exclusively resorting to criticisms of political involvement in administration.

The second pillar upon which statutory supremacy rests its case is similarly uncompelling: the belief that agencies are best understood as agents of Congress, and agencies' consideration of extra-statutory factors serves to weaken Congress's control of administration and enhance the President's. Statutes serve as the most fundamental method of congressional control of administration, ${ }^{127}$ and in this sense, any agency

125. Pierce, Factors an Agency Can Consider, supra note 1, at 80.

126. In defense of the over-inclusive prohibition on extra-statutory considerations, one might argue that both implementing agencies and reviewing courts have great difficulty distinguishing between expertise-enhancing and expertise-impeding extra-statutory factors, and that the corrosive threat of expertise-impeding factors such as political pressure justifies the absolute prohibition on extra-statutory considerations. That courts would be unable to distinguish between logically relevant factors that Congress neglected to include in the list of statutorily authorized considerations and politically-motivated pressure from the President is not inconceivable, but unlikely for two reasons. First, the politically-motivated considerations are more likely to be removed from the broader statutory scheme in which the agency acts, meaning the reviewing court should be able to distinguish political considerations from those considerations embedded within the purpose if not the text of the statute. The Court in Massachusetts v. EPA, for example, was able to reject as politically-motivated EPA's concerns about the foreign policy implications for deciding to categorize greenhouse gas emissions as pollutants because the Clean Air Act does not authorize EPA to justify decisions with reference to foreign affairs. 549 U.S. 497, 534 ("Congress authorized the State Department - not EPA - to formulate United States foreign policy with reference to environmental matters relating to climate."). Second, and to the extent that political pressure may align itself with statutorily authorized considerations, that pressure will be unlikely to find the same scientific or technical support in the record, rendering political pressure susceptible to discovery under substantive review. Professor Heinzerling, supra note 21, at 928, demonstrates that consequences for an agency found to be acting in bad faith may be particularly severe: "when an agency breaks all of these rules at once ... it can expect not only an icy judicial reaction, but also, if the issue is important enough, an existential crisis within the ranks of the agency itself." Thus, even the possibility of a court recognizing an agency's masked political considerations may be sufficient to deter such behavior.

127. Jack M. Beermann, Congressional Administration, 43 SAN DIEGO L. REV. 61, 73 (2006) [hereinafter Beermann, Congressional Administration]. The creation of a particular agency insulated from presidential control, or the delegation of regulatory authority to an agency already insulated from presidential control illustrates the broad ways in which Congress utilizes legislation to control administration. Jonathan R. Macey, Separated Powers and Positive Political Theory: The Tug of War over Administrative Agencies, 80 GEO. L.J. 671 (1992) (distinguishing between ex ante and ex poste congressional controls of administration). 
divergence from the text of the statute marks a divergence from congressional control of administration. This divergence is especially troubling when Congress delegates authority with precise instruction for implementation. ${ }^{128}$ As with the unitary executive model, proponents of congressional control of agencies may argue that the view of agencies as agents of Congress is constitutionally mandated. ${ }^{129}$ The claim that consideration of extra-statutory factors enhances presidential control of administration relative to congressional control rests upon an intuitive assumption: because of various institutional structures such as the Office of Budget and Management that place agencies under the immediate control of the White House, the White House is more likely to be able to coerce agencies into considering presidential priorities than is Congress. ${ }^{130}$ Judicial review, congressionally authorized and structured by the APA, thus serves as the mechanism by which Congress counters enhanced presidential control of administration.

For this reason, statutory supremacists doctrinally advocate for courts to use the first of State Farm's instances of arbitrary and capricious decision-making - "if the agency has relied on factors which Congress has not intended it to consider" ${ }^{\prime 131}$ - to invalidate agency action that relies upon any factor other than those specified by Congress in the agency's authorization or mandate. Much to the frustration of statutorysupremacists, however, courts have relied upon the dual ambiguities inherent in State Farm's exhortation that agencies not (a) rely upon factors which Congress did not (b) intend it to consider. First, in administrative processes, "relied" creates significant ambiguity: did the Supreme Court in State Farm preclude agencies from considering those factors Congress has not intended it to consider, or did the Supreme Court only require agencies to justify administrative outcomes by

128. See, e.g., Biodiversity Assocs. v. Cables, 357 F.3d 1152, 1162 (10th Cir. 2004) (noting that "the executive role of 'taking Care that the Laws be faithfully executed,' is entirely derivative of the laws passed by Congress" so long as "Congress is exercising its own powers with respect to matters of public right").

129. William W. Van Alstyne, The Role of Congress in Determining Incidental Powers of the President and of the Federal Courts: A Comment on the Horizontal Effect of the Sweeping Clause, 40 LAW \& CONTEMP. ProBs. 102, 118 (1976). Also like with the unitary executive theorists, the ultimate merits of this constitutional interpretation reside beyond the scope of this Article because the question addressed here of the factors upon which an agency may base its decision is unlikely to be dispositive.

130. Alan B. Morrison, OMB Interference with Agency Rulemaking: The Wrong Way to Write a Regulation, 99 HARV. L. ReV. 1059, 1063 (1986); Thomas O. McGarity, Presidential Control of Regulatory Agency Decisionmaking, 36 AM. U.L. REV. 443, 446-47 (1987). But see Beermann, Congressional Administration, supra note 127.

131. Motor Vehicle Mfrs. Ass'n v. State Farm Mut. Auto Ins. Co., 463 U.S. 29, 43. 
reference to statutorily permissible factors and thereby permit agencies to consider but not rely upon extra-statutory factors? As a practical matter, it would seem exceedingly difficult for reviewing courts to prohibit agencies from even considering political factors, especially if such considerations occurred outside the record or under the guise of scientific or technical disputes. ${ }^{132}$ Indeed, courts have accepted agencies considering political factors to decide on a course of action so long as the agency could justify all of the potential outcomes by reference to statutorily-authorized considerations. ${ }^{133}$

More commonly, however, courts have relied upon the ambiguous notion of congressional intent to avoid limiting agency justifications for an administrative outcome to those considerations expressly contained in the agency's authorizing statute. This possibility emerged out of the Chevron decision only a year after State Farm, suggesting courts recognize that the agency is best situated to derive the statutorily permissible factors upon which it may implement its statutory authorization, and defer to the agency's statutory construction of ambiguous statutes. ${ }^{134}$ The statutory text, of course, provides only one indication of congressional intent, and not necessarily a dispositive one with regard to the factors upon which an agency may make a decision. ${ }^{135}$ The following Part summarizes the ways in which courts have attempted to approximate congressional intent regarding the factors an agency may consider since Chevron and State Farm were decided over three decades ago. The answers, by and large, have frustrated proponents of statutory supremacy.

\section{Doctrines OF DifFERENTIAL DEFERENCE: THE CONTINGENT APPROACHES}

As a preliminary matter, Section III.A will explain both the centrality of Chevron deference to agency determinations of permissible factors for consideration, and the ways in which these determinations suggest reformulating the domain ${ }^{136}$ of Chevron deference. Before evaluating the

\footnotetext{
132. Watts, Proposing a Place, supra note 15, at 13.

133. EDLEY, supra note 89, at 193; Pierce, Factors an Agency Can Consider, supra note 1 (arguing that only in instances where the statute mandates action contingent upon particular considerations is the agency unable to resort to other factors as a justification for an administrative outcome).

134. Chevron U.S.A., Inc. v. Nat'1 Res. Def. Council, Inc., 467 U.S. 837 (1984).

135. See John F. Manning, Textualism and Legislative Intent, 91 VA. L. REV. 419 (2005).

136. This Article distinguishes between the "content" and "domain" of Chevron deference. Content refers to the level of review applied, while the domain refers to the conditions under which
} 
doctrines governing the conditions under which courts grant Chevron deference, ${ }^{137}$ it is necessary to understand what is at stake: the degree of deference sought. Accordingly, Section III.A will attempt to demonstrate the two assumptions upon which the rest of the Article proceeds: (1) Chevron continues to amount to the primary doctrinal framework governing agency's derivations of permissible factors for consideration and (2) those derivations of permissible factors for consideration continue to structure Chevron's Step Two reasonableness test.

The remaining two Sections examine two sets of conditions under which courts grant administrative agencies deference in their statutory constructions of the factors that Congress intended the agencies to consider when implementing a particular delegation. The first approach is the one that courts have adopted, whether willingly or by circumstance, over the past three decades: Chevron Step Zero. ${ }^{138}$

Chevron Step Zero encompasses the evolving set of conditions under which courts grant deference to agency interpretations of law. When first articulated in 1984, the only necessary condition for an agency to receive deference seemed to be that the relevant language in the relevant statute be ambiguous. ${ }^{139}$ Over time, courts narrowed the domain of Chevron, arriving at a set of conditions necessary for an agency's interpretation to receive deference. Those conditions require not only that the relevant statutory language be sufficiently ambiguous, but also that the agency implement its interpretation with "the force of law," 140 that the agency be the primary agency tasked with the implementation of the regulatory regime of which the ambiguous statute is part, ${ }^{141}$ and that the ambiguity not concern a question of major economic or political significance. ${ }^{142}$ Taken cumulatively, these cases narrowing the number

\footnotetext{
that deference is granted.

137. Infra Section III.B.

138. Sunstein, supra note 65.

139. Chevron U.S.A., Inc. v. Nat'1 Res. Def. Council, Inc., 467 U.S. 837, 843 (1984) (“'II]f the statute is silent or ambiguous with respect to the specific issue, the question for the court is whether the agency's answer is based on a permissible construction of the statute.").

140. United States v. Mead Corp., 533 U.S. 218 (2001) (establishing most explicitly the socalled "Chevron Step Zero" doctrine, which grants Chevron deference only when agencies have exercised delegated power to act with the force of law). Christensen v. Harris Cty., 529 U.S. 576 (2000), excluded interpretive regulations from Chevron's domain, requiring agencies issue legislative regulations to receive Chevron deference when promulgating regulations.

141. See, e.g., Martin v. Occupational Safety \& Health Review Comm'n, 499 U.S. 144, 152-53 (1991) (granting greater deference to the Secretary of Labor's construction of a statute than that of the OSHRC).

142. See, e.g., King v. Burwell, 135 S. Ct. 2480, 2488-89 (2015).
} 
and type of agency actions entitled to Chevron deference demonstrate that "the deference rule has become disconnected from [the] considerations relating to presidential involvement" 143 that both commentators and members of the court initially considered fundamental.

Simultaneously, and the likely cause of the narrowing of Chevron's domain, doctrine has crystallized around the likely fictitious notion of congressional intent as the foundational justification for the Chevron doctrine. ${ }^{144}$ Following the doctrinal summary that illustrates this evolution in justification, then, this Part argues that the necessary conditions for the application of Chevron deference are ill-suited for the realization of both the original and reformulated aims animating the Chevron doctrine. The Supreme Court's attempt to weld a Chevron doctrine initially concerned with promoting administrative accountability through presidential control and facilitating agency employment of technical expertise onto a legal fiction of legislative intent has undermined administrative accountability, technocracy, and indeed, Congress's intent. Section III.C thus argues for a streamlined alternative: courts should grant greater deference to executive agency's interpretations of ambiguous statutes than to those of independent agencies.

143. Kagan, supra note 10, at 2373. See also Sunstein, supra note 65, at 191 (arguing the application of Chevron deference has become far too limited under Step Zero).

144. See Encino Motorcars, LLC v. Navarro, 136 S. Ct. 2117, 2125 (2016) (“A premise of Chevron is that when Congress grants an agency the authority to administer a statute by issuing regulations with the force of law, it presumes the agency will use that authority to resolve ambiguities in the statutory scheme."); Sunstein, supra note 65, at 192 (noting that both views of Chevron holding sway over the Supreme Court "converged... on a distinctive understanding of Chevron, one that roots the decision in a theory of implicit congressional delegation of lawinterpreting power to administrative agencies. Both [views] explicitly recognized that any understanding of legislative instructions is a 'legal fiction' ...."); Thomas W. Merrill \& Kristin E. Hickman, Chevron's Domain, 89 GEO. L.J. 833, 836 (2001) ("The Supreme Court in recent years has endorsed the notion that Chevron rests on implied congressional intent."). How this notion of Chevron as a presumption of legislative intent squares with even more recent developments like the "major question" doctrine, see, e.g., King v. Burwell, 135 S. Ct. at 2488-89, remains unclear. Worth noting, however, is the even greater inability of the "political accountability" understanding of Chevron to account for the "major questions" doctrine. Indeed, if Chevron deference were primarily motivated by concerns for democratic accountability, it would make little sense for courts to defer to agencies' interpretations on only those statutory constructions of relative insignificance while retaining more searching review for the questions of major economic and political importance where, presumably, democratic accountability should be of even greater relevance. This is not to argue against the "major questions" doctrine, but only to note (1) that the doctrine cannot decisively resolve disputes about the justifications supporting Chevron deference as (2) the doctrine appears incompatible with most of the concerns animating Chevron deference. 


\section{A. Chevron Deference: Relevance and Stakes}

Chevron deference is best understood as a development in the standard by which courts consider one particular subset of agency decisions subject to arbitrary and capricious review as articulated in State Farm. $^{145}$ State Farm, which remains the seminal expression of the arbitrary and capricious review standard, provided four circumstances in which "normally, an agency rule would be arbitrary and capricious", including "if the agency has relied on factors which Congress has not intended it to consider." 146 Accordingly, any judicial application of substantive $^{147}$ arbitrary and capricious review requires judicial determinations of congressional intent concerning the factors upon which an agency may rely. ${ }^{148}$ Chevron provides the specific test with which courts review agency interpretations of statutes to derive permissible factors for consideration: (1) "whether Congress has directly spoken to the precise question at issue", and (2) if the statute is ambiguous indicating Congress has not directly addressed the question, "the

145. Motor Vehicle Mfrs. Ass'n v. State Farm Mut. Auto. Ins. Co., 463 U.S. 29 (1983). See also Kenneth A. Bamberger \& Peter L. Strauss, Chevron's Two Steps, 95 VA. L. REV. 611, 621-22 (2009) ("Courts and commentators have converged on an emerging consensus that the 'arbitrary, capricious, and abuse of discretion' standard set forth in Section 706(2)(A) supplies the metric for judicial oversight at Chevron's second step.").

146. State Farm, 463 U.S. at 43 . The other three instances of arbitrary and capricious action are: "entirely failed to consider an important aspect of the problem, offered an explanation for its decision that runs counter to the evidence before the agency, or is so implausible that it could not be ascribed to a difference in view or the product of agency expertise." Id.

147. Arbitrary and capricious review, including as employed by the Court in State Farm, has traditionally been understood as more procedural than substantive. See, e.g., Encino Motorcars, LLC v. Navarro, 136 S. Ct. 2117, 2125 (2016) (implying a distinction between State Farm review of procedural defects in the administrative process, where "[o]ne of the basic procedural requirements of administrative rulemaking is that an agency must give adequate reasons for its decisions", and Chevron deference towards agency constructions of law). As in other areas of law where the procedure-substance binary blurs under close inspection, judicial determinations of what amount to "adequate reasons for its decisions" appear more substantive than procedural, especially where those determinations require constructions of statutes to derive the reasons for agency action the relevant statute authorizes or even mandates. Accordingly, this Article refers to the first State Farm condition of "arbitrary and capricious agency action" as substantive arbitrary and capricious review. At risk of unnecessarily complicating matters, it is also worth noting that judicial invalidation of agency action for justifying an administrative outcome with reference to a statutorily impermissible consideration may not strictly fall under "arbitrary and capricious" action, but instead "otherwise not in accordance with law", the less frequently referenced third justification for holding agency action unlawful under 5 U.S.C. $§ 706(2)$ (A) (2012). State Farm's characterization of agencies relying upon considerations Congress did not intend that agency to consider firmly placed such analysis under the "arbitrary and capricious" prong for invalidating agency action, however.

148. See Gersen \& Vermuele, supra note 6, at 1371. State Farm's relevant factor test exists "simply to ensure that the agency has given due consideration to any factors made relevant by the authorizing statute itself, and to ensure that the agency has not considered any factors that the statute rules off-limits." Id. 
question for the court is whether the agency's answer is based on a permissible construction of the statute."149

While the Chevron doctrine's relevance to substantive arbitrary and capricious review is undeniable, it is not immediately apparent that the doctrine is best understood as refining the standard with which courts review an agency's interpretation of a statute to derive the factors that an agency may consider when implementing that statute. ${ }^{150}$ Indeed, Chevron extends to other legal determinations an agency may promulgate, well beyond derivations of statutorily permissible decisional factors. ${ }^{151}$ Nonetheless, agencies' derivations of the permissible factors for consideration are a precondition to any other form of statutory construction that follows. ${ }^{152}$ Even in Chevron, the court could only review the EPA's definition of the term "source" within the context of the relevant statutory framework's aims - "accommodat[ing] progress in reducing air pollution with economic growth"- ${ }^{153}$, which constitute the permissible factors for consideration. It is neither controversial nor novel to state that any statutory interpretation necessarily entails a construction of statute's purposes, which then constitute at least part of the metric against which that interpretation is evaluated. ${ }^{154}$ The reason giving that forms the foundation of judicial review for those interpretations that an agency implements through rulemaking or adjudicatory processes ${ }^{155}$ renders obvious the centrality to judicial review of the factors an agency considered. ${ }^{156}$ Such review asks not only whether the reasons the agency provided in fact support the interpretation rendered, but also whether the agency was permitted to rely upon or even consider those reasons provided. Yet, the centrality to Chevron deference of agencies' statutory derivations of permissible factors for

149. Chevron, U.S.A., Inc. v. Nat'1 Res. Def. Council, Inc., 467 U.S. 837, 842-43 (1984).

150. The Chevron court does not cite State Farm once in the decision. Id.

151. The Chevron decision itself only implicitly involved questions of permissible considerations in the Court's "Step Two" analysis. Id. at 866 ("We hold that the EPA's definition of the term 'source' is a permissible construction of the statute which seeks to accommodate progress in reducing air pollution with economic growth." (emphasis added)).

152. Pierce, How Agencies Should Give Meaning, supra note 1, at 204 (characterizing agency derivations of permissible factors as the link between policymaking and statutory interpretation, ensuring the presence of the former necessitates the presence of the latter); Gersen \& Vermeule, supra note 6 , at $1372-73$.

153. Chevron, 467 U.S. at 866.

154. See, e.g., John F. Manning, The New Purposivism, 2011 SuP. CT. REV. 113, 115 (2011)

155. See infra Section III.B. for a discussion of Chevron Step Zero and the ways in which an agency implements a particular interpretation implicate the deference with which courts review that interpretation.

156. Short, supra note 16, at 1821; Mashaw, supra note 4, at 111, (arguing that reason giving is a "protector of judicial review"); Bressman, Beyond Accountability, supra note 19, at 528. 
consideration has received little direct attention from scholars. ${ }^{157}$ The account that follows attempts to rectify this oversight.

Courts' assessment of the reasonability of the agency's statutory interpretation under Chevron Step Two can be reduced to two deferential evaluations of administrative action. ${ }^{158}$ First, and as a precondition to the second, an assessment of the reasonability of the agency's derivation of the aims of the statute, which amount to the permissible considerations upon which an agency may justify a particular course of action; ${ }^{159}$ and, second, an assessment of whether the agency's interpretation reasonably

157. Academic treatments of Chevron Step Two have generally argued (1) normatively that courts should merge Chevron Step Two into arbitrary and capricious review, see Ronald M. Levin, The Anatomy of Chevron: Step Two Reconsidered, 72 CHI.-KENT. L. Rev. 1253, 1261 (1997); and, (2) descriptively that such a doctrinal development has already occurred. Id. at 1267; Matthew C. Stephenson \& Adrian Vermeule, Chevron Has Only One Step, 95 VA. L. ReV. 597, 604 (2009) ("We have the doctrinal equivalent of musical chairs, with three doctrines (Chevron Step One, Chevron Step Two, State Farm) and only two chairs (interpretive reasonableness and reasoned decisionmaking)."). Professors Stephenson and Vermeule's colorful analogy makes clear where this Article's understanding of Chevron diverges from existing scholarship: Chevron Step Two does not compete with State Farm, but rather refines a particular kind of review for reasoned decision making, specifically in an agency's decision-making process for arriving at a statutory interpretation of an ambiguous authorization. Accordingly, calls to merge the two doctrines amount to a call for a return to the short-lived post-State Farm (1983) but pre-Chevron (1984) era. While the standards bear close resemblance, there are crucial distinctions in that State Farm amounts to "a much stricter and more exacting review of the agency's rationale and decision-making process than the Chevron Step Two standard." Catskill Mountains Chapter of Trout Unlimited, Inc. v. EPA, 846 F.3d 492, 521 (2d Cir. 2017) ("[W]e conclude that [the District Court] erred by incorporating the State Farm standard into its Chevron Step Two analysis and thereby applying too strict a standard of review."); Kenneth A. Bamberger \& Peter L. Strauss, Chevron's Two Steps, 95 VA. L. Rev. 611, 622 (2009). Chevron Step Two is distinct in its "doubly deferential" nature. The review is doubly deferential in the sense that the court reviews deferentially both (1) the agency's derivation of the statute's aims and permissible factors for consideration, and (2) the agency's interpretation as mechanism for furthering those aims. Whether the level of deference with which the court reviews (1) from (2) varies marks an interesting question for further research, though a likely futile one due to the Court's general ambiguity about what deference entails and the uncommon nature of detailed Chevron Step Two analyses. Dicta from Justice Ginsburg's majority opinion in Lopez v. Davis, 531 U.S. 230, 242 (2001) implies the standards are similar. Infra notes 159 et seq.

158. To avoid "Chevron Step-counting fatigue", see, e.g., Daniel J. Hemel \& Aaron L. Nielson, Chevron Step One-and-a-Half, 84 U. CHI. L. REV. 757, 758 (2017), it seems unnecessary to characterize these two processes as distinct steps. Rather, they may be best understood as the dual processes by which doubly deferential review of statutory interpretation occurs.

159. Justice Breyer's formulation of the doctrine in Barnhart v. Walton, 535 U.S. 212 (2002) illustrates that Chevron Step Two amounts to judicial review of the agency's construction of the statutorily permissible factors for consideration upon which the agency justified the challenged interpretation. Justice Breyer characterizes Step Two as an assessment of "whether the interpretation, for other reasons, exceeds the bounds of the permissible." Id. at 218 (emphasis added). The paragraph of the decision in which Justice Breyer conducts this assessment makes clear that the "other reasons" are "the statute's basic objectives", rendering Chevron Step Two an assessment of whether the agency's interpretations "makes considerable sense in terms of [those objectives]". Id. at 219 . 
furthers the identified statutory aims. ${ }^{160}$ In short, Chevron amounts to a doubly-deferential - insofar as reviewing for "reasonability" amounts to a deferential standard-review of an agency's legal interpretations because the court grants deference to both (1) the agency's construction of permissible factors for consideration and (2) the agency's interpretation of a contested provision that derives support from the permissible factors for consideration. ${ }^{161}$ Indeed, the premise of Chevron deference is that a court will defer to the agency's expertise-informed and relatively more politically accountable perspective for realizing a particular set of aims, ${ }^{162}$ so long as the court agrees that the set of aims an agency seeks to realize are a reasonable construal of the set of aims contained in the statute that Congress tasked that agency to implement. ${ }^{163}$ While the Supreme Court has never expressly identified as distinct these two assessments, two things are clear. First, that both fall under Chevron Step Two. Second, while generally implicit, the assessment of the reasonability of the agency's derivation of the aims of the statute is a precondition to an assessment of the reasonability of the agency's interpretation as a means for the realization of those statutory aims.

In some applications of Chevron deference, the court rejects as unreasonable the agency's derivation of permissible factors for consideration. Michigan v. EPA, ${ }^{164}$ for example, concerned only whether it was reasonable for the EPA to interpret "appropriate and necessary" as not requiring consideration of costs at particular stage in the rulemaking process. $^{165}$ In a relatively rare instance of rejecting an agency

160. Even if the agency were to derive the statutory objectives-and thus factors for consideration-with sufficient accuracy, however, it remains possible for the court to view the agency's interpretation as undermining those statutory aims. This outcome is highly unlikely because of the very reasons the doctrine exists: agency's comparatively superior expertise and political accountability vis-à-vis courts' counsel against demanding judicial review of an agency's determinations of the interpretation that best fulfills the statutory aims. Chevron, U.S.A., Inc. v. Nat'l Res. Def. Council, Inc., 467 U.S. 837, 866 (quoting United States v. Shimer, 367 U.S. 374, 383 (1961)) ("The Regulations which the Administrator has adopted provide what the agency could allowably view as ... [an] effective reconciliation of these twofold ends . ...").

161. Id. at $842-43$.

162. Id. at 865 ("Judges are not experts in the field, and are not part of either political branch of the Government. Courts must, in some cases, reconcile competing political interests, but not on the basis of the judges' personal policy preferences. In contrast, an agency to which Congress has delegated policy-making responsibilities may, within the limits of that delegation, properly rely upon the incumbent administration's views of wise policy to inform its judgments.").

163. Id.

164. 135 S. Ct. 2699 (2015).

165. Id. at 2704 ("The Clean Air Act directs the Environmental Protection Agency to regulate emissions of hazardous air pollutants from power plants if the Agency finds regulation 'appropriate and necessary.' We must decide whether it was reasonable for EPA to refuse to consider cost when making this finding."). 
interpretation at Chevron Step Two, ${ }^{166}$ the Justice Scalia-authored bare majority in Michigan v. EPA, held that "appropriate and necessary" was ambiguous but that the agency's interpretation disregarding costs was unreasonable because "appropriate and necessary" mandated consideration of costs. Accordingly, because the agency unreasonably identified the permissible factors for consideration from the statutory aims, the Court found it unnecessary to assess whether the agency's interpretation reasonably furthered the permissible considerations or statutory aims. In another demonstration of the centrality of agency's derivation of permissible factors to Chevron Step Two, the majority in Lopez v. Davis ${ }^{167}$ upheld as reasonable both the agency's derivation of those permissible factors for consideration and the interpretation of the statute with which the agency furthered those factors. "By denying eligibility to violent offenders, the statute manifests congressional concern for preconviction behavior - and for the very conduct leading to conviction. The Bureau may reasonably attend to these factors as well." 168

Lopez and Michigan are the outliers, however. In most applications of Chevron Step Two, the court only implicitly assesses whether the agency reasonably derived permissible considerations or statutory aims before proceeding to evaluate whether those permissible considerations reasonably supported the interpretation promulgated. In these cases, where Chevron Step Two most closely resembles State Farm substantive review, the court's primary assessment is the more technical determination of whether the agency's statutory interpretation furthers the implicitly derived statutory purposes. ${ }^{169}$ In Mayo Foundation for Medical Education and Research v. United States, for example, the Court held " $[\mathrm{t}]$ he Department reasonably determined that taxing residents

166. For over a decade after Chevron, “the Court ha[d] never once struck down an agency's interpretation by relying squarely on the second Chevron step... when [the Court] utilizes the Chevron framework, it either upholds the agency or reverses on the strength of step one." Levin, supra note 157 , at 1261 .

167. 531 U.S. $230(2001)$.

168. Id. at 242 (emphasis added). For a similar decision outside the context of Chevron, see INS v. Yang, 519 U.S. 26, 30-31 (1996) ("Unlike the prior version of the waiver-of-deportation statute ... under which the Attorney General had no discretion to deny a waiver if the statutory requirements were met, satisfaction of the requirements under $\S 1251(\mathrm{a})(1)(\mathrm{H})$, including the requirement that the alien have been 'otherwise admissible,' establishes only the alien's eligibility for the waiver. Such eligibility in no way limits the considerations that may guide the Attorney General in exercising her discretion to determine who, among those eligible, will be accorded grace." (emphasis added)).

169. But see Stephenson \& Vermeule, supra note 157, at 606, for the ways in which these doctrines diverge. 
under FICA would further the purpose of the Social Security Act", without explicitly reviewing the agency's construction of the purpose of the Social Security Act. ${ }^{170}$ In Whitman v. American Trucking Assn, the Court held that EPA's interpretation implementing a provision of the Clean Air Act could not withstand Chevron Step Two review because the interpretation was "so at odds with [the statute's] manifest purpose."171 In most instances in which the Supreme Court reaches Chevron Step Two, the Court's approach more closely resembles Mayo and Whitman than Lopez or Michigan. Review of the initial statutory construction for purpose or permissible factors remains largely implicit, and the circuit court decisions to have explicitly addressed the question provide little clarification. ${ }^{172}$

These Supreme Court rulings make clear that Chevron Step Two will continue to provide the standard by which courts review agency's

170. 562 U.S. $44,59(2011)$

171. 531 U.S. 457, 485-86 (2001). The uncertainty over whether the Court held to be unreasonable EPA's construction of statutorily permissible factors for consideration or the interpretation as a mechanism for realizing the aims articulated in those factors is illustrative of a more general uncertainty surrounding Chevron Step Two. Other aspects of the Court's complex ruling in American Trucking more explicitly implicate agency's derivations of permissible factors for consideration. Id. at 469 (rejecting American Trucking Associations' claim that the agency may consider costs even if the statute did not include costs in the enumerated permissible considerations because "[t]hat factor is both so indirectly related to public health [the enumerated permissible consideration] and so full of potential for canceling the conclusions drawn from direct health effects that it would surely have been expressly mentioned ... had Congress meant it to be considered." (emphasis in original)). The unique posture of American Trucking - where the respondent sought judicial review to force the agency to consider an unenumerated but potentially permissible factorrendered irrelevant Chevron deference to this question. While the court only needed to find that the statute did not mandate consideration of costs, the language quoted above strongly implies that had the agency considered costs, the court would have found that interpretation of the statute unreasonable under Chevron Step Two.

172. Professor Pierce, Facts an Agency Can Consider, supra note 1, at 73, praises the D.C. Circuit's approach of concluding "that Congress has forbidden an agency from considering a logically relevant decisional factor only when 'there is clear congressional intent' to preclude agency consideration of the factor." But see Bluestone Energy Design, Inc. v. F.E.R.C., 74 F.3d 1288, 1294-95 (D.C. Cir. 1996) ("Because the Commission's power to assess penalties comes from Congress, the Commission can consider only those factors that Congress has specified .... Because the Federal Power Act does not directly address the propriety of considering staff time and resources, we turn to the second step of Chevron, testing for reasonableness the Commission's view that use of staff time and resources is relevant to the statutory factors.... and we do not find persuasive the ALJ's explanation."). The Fifth Circuit's approach is similarly muddled. Luminant Generation Co., L.L.C. v. EPA, 675 F.3d 917, 926 (5th Cir. 2012), for example, suggests a statutorysupremacy approach: "It is beyond cavil that the EPA may consider only the requirements of the CAA when reviewing SIP submissions." In other cases, however, the Fifth Circuit employs a far more deferential test borrowed from its elucidation of State Farm review: "the scope of the reviewing court's inquiry is to determine if the agency's judgment conforms to minimum standards of rationality, i.e., whether the agency act bears a rational relationship to the statutory purposes, and whether there is substantial evidence in the record to support it." ConocoPhillips Co. v. EPA, 612 F.3d 822, 832 (5th Cir. 2010). 
derivation of statutory permissible factors, so long as the conditions discussed in the following Section are met, and the agency's derivation of those factors will continue to inform the second evaluation that occurs under Chevron Step Two, whether the agency's interpretation is reasonable in light of the permissible factors for consideration. Even if commentators have overstated the impact of Chevron deference, ${ }^{173}$ both empirical studies ${ }^{174}$ and the tremendous time and effort expended by the Supreme Court over the conditions under which Chevron deference applies ${ }^{175}$ strongly imply a continued significance attached to Chevron deference. Facially, at least, Chevron Step Two is undeniably more deferential than its alternative, ${ }^{176}$ Skidmore persuasiveness deference, ${ }^{177}$ and its availability is often enough dispositive in judicial review of agency action. ${ }^{178}$

\section{B. Chevron's Domain: Step Zero, the Force of the Law, and Chevron- Eligibility}

With the enhanced level of deference Chevron provides to the administrative actions that fall within its domain, ${ }^{179}$ increased attention has fallen on the conditions under which agency actions receive Chevron deference. ${ }^{180}$ The remaining sections of this Article examine the doctrine

173. Connor N. Raso \& William N. Eskridge, Jr., Chevron as a Canon, Not a Precedent: An Empirical Study of What Motivates Justices in Agency Deference Cases, 110 COLUM. L. REV. 1727 (2010); William N. Eskridge, Jr. \& Lauren E. Baer, The Continuum of Deference: Supreme Court Treatment of Agency Statutory Interpretation from Chevron to Hamdan, 96 GEO. L.J. 1083, 1090 (2008) (concluding “there has not been a Chevron 'revolution' at the Supreme Court level.").

174. Peter H. Schuck \& E. Donald Elliott, To the Chevron Station: An Empirical Study of Federal Administrative Law, 1990 DUKE L.J. 984 (1990).

175. See infra Section III.B.

176. Schuck \& Elliot, supra note 174.

177. Jim Rossi, Respecting Deference: Conceptualizing Skidmore Within the Architecture of Chevron, 42 WM. \& MARY L. REV. 1105, 1137-46 (2001) (reading Skidmore as a heightened form of reasonableness review); Amy J. Wildermuth, Solving the Puzzle of Mead and Christensen: What Would Justice Stevens Do?, 74 Fordham L. REV. 1877, 1896-1906 (2006); Kristin E. Hickman \& Mathew D. Krueger, In Search of the Modern Skidmore Standard, 107 Colum. L. REV. 1235, 127180 (2007) (arguing that courts have inexpertly applied a Skidmore deference along a continuum).

178. See, e.g., City of Arlington v. FCC, 569 U.S. 290, 314 (2013) (Roberts, C.J., dissenting) ("When it applies, Chevron is a powerful weapon in an agency's regulatory arsenal.").

179. Throughout this Section, Chevron's domain refers to the conditions under which Chevron applies. The phrase originates with Merrill \& Hickman's influential article, Chevron's Domain, supra note 144, which was cited affirmatively by the Court in United States v. Mead Corp., 533 U.S. 218 (2001), the case most frequently associated with demarcations of Chevron's domain. This Section uses the phrase interchangeably with Chevron Step Zero, another phrase encompassing courts' assessments of conditions under which an agency's legal interpretation receives Chevron deference. Sunstein, supra note 65.

180. Sunstein, supra note 65, at 187. 
currently conditioning agency access to Chevron deference, and then argue for a reformulation of that doctrine. Initially, Chevron applied to any agency's interpretations of an ambiguous statute. ${ }^{181}$ In 1984, at least, the manner in which an agency interpreted that ambiguous statutory provision had little relevance to the question of whether the judiciary would grant deference to that interpretation. The lack of emphasis on the administrative process the agency employed to interpret an ambiguous provision reflected the emphasis on the possible justifications for Chevron deference provided by Justice Stevens in his majority opinion. ${ }^{182}$ While no doubt significant, ${ }^{183}$ Congressional intent seems to occupy a role of secondary importance relative to concerns for political accountability and agency expertise. ${ }^{184}$ The narrowing of Chevron's domain that follows thus tracks the narrowing of the court's justification for granting Chevron deference, as congressional intent has displaced political accountability and expertise. ${ }^{185}$

Both scholars and jurists have shifted the emphasis of justifications for Chevron deference from expressly normative claims for presidential control as a mechanism of political accountability ${ }^{186}$ to claims about the merits of the doctrine as a tool to derive congressional intent. ${ }^{187}$ The

181. Chevron, U.S.A., Inc. v. Nat. Res. Def. Council, 467 U.S. 837, 842-43 (1984). ("First, always, is the question whether Congress has directly spoken to the precise question at issue. If the intent of Congress is clear, that is the end of the matter; for the court, as well as the agency, must give effect to the unambiguously expressed intent of Congress.").

182. Id. at 866 (emphasizing the political accountability justifications for Chevron deference by arguing that "federal judges - who have no constituency — have a duty to respect legitimate policy choices made by those who do").

183. As reflected in Chevron Step One. Id.

184. Id. ("When a challenge to an agency construction of a statutory provision, fairly conceptualized, really centers on the wisdom of the agency's policy, rather than whether it is a reasonable choice within a gap left open by Congress, the challenge must fail. In such a case, federal judges - who have no constituency - have a duty to respect legitimate policy choices made by those who do."); Lisa Schultz Bressman, Procedures as Politics in Administrative Law, 107 ColuM. L. REV. 1749, 1765 (2007) [hereinafter Bressman, Procedures as Politics]; Kagan \& Barron, supra note 54 , at 213.

185. Kagan, supra note 10, at 2373; Kagan \& Barron, supra note 54, at 212 (“Mead represents the apotheosis of a developing trend in Chevron cases: the treatment of Chevron as a congressional choice, rather than either a constitutional mandate or a judicial doctrine."); City of Arlington v. FCC, 569 U.S. 290, 321-22 (2013) (Roberts, C.J., dissenting) ("Adams Fruit, Mead, and Gonzales thus confirm that Chevron deference is based on, and finds legitimacy as, a congressional delegation of interpretive authority. An agency interpretation warrants such deference only if Congress has delegated authority to definitively interpret a particular ambiguity in a particular manner.").

186. Id. But see Strauss, supra note 15, at 752 ("To make Chevron turn entirely on presidential politics is to omit consideration of the role of "reasonableness" in relation to those matters found to fall within the area of discretion constituting "step two" of its analysis.").

187. Sunstein, supra note 65, at 192 (noting that both views of Chevron holding sway over the Supreme Court "converged ... on a distinctive understanding of Chevron, one that roots the decision in a theory of implicit congressional delegation of law-interpreting power to administrative agencies. 
latter claim emerges in a self-fulfilling manner from the doctrine's prominence. The doctrine's merit as an interpretive presumption relies at least in part upon congressional knowledge that courts will grant agencies' statutory constructions deference, a knowledge that courts can presume Congress possesses with increasing certainty so long as Chevron deference remains in place. ${ }^{188}$ This circularity offers a partial explanation for the development of the justifications for the Chevron doctrine: first grounded in the normative claims necessary to establish the doctrine as a productive interpretive presumption and only later emphasized as an accurate method for deriving congressional intent once courts could reasonably claim that Congress, with knowledge of the doctrine, intended to implicitly delegate through ambiguity.

Three cases, cumulatively referred to as "Chevron Step Zero", ${ }^{189}$ mark this transition to congressional intent as the dominant justification for Chevron deference. ${ }^{190}$ First is Christensen v. Harris County, holding that opinion letters issued by the Acting Administration of the Wage and Hour Division of the Department of Labor, "like interpretations contained in policy statements, agency manuals, and enforcement guidelines, all of which lack the force of law [,] do not warrant Chevron style deference." 191 Later, the majority added a second consideration, the process by which the agency enacted the relevant statutory interpretation, with the implication that the court was more willing to apply Chevron deference when the agency issued its interpretation following somewhat

Both [views] explicitly recognized that any understanding of legislative instructions is a 'legal fiction' . . ."); Merrill \& Hickman, supra note 144, at 836.

188. Abbe R. Gluck \& Lisa Schultz Bressman, Statutory Interpretation from the Inside-An Empirical Study of Congressional Drafting, Delegation, and the Canons: Part 1, 65 STAN. L. ReV. 901, 995 (2013) (arguing that Chevron is a feedback canon).

189. Sunstein, supra note 65.

190. Whether these cases required this transition remains unresolved. It is possible, if not inevitable, that agencies both exercise their technical expertise to a greater extent and act with greater political accountability when implementing statutory interpretations through actions with the force of law. The Supreme Court, however, declined to pursue these justifications when narrowing the domain of Chevron, perhaps wisely. See, e.g., Sunstein, supra note 65, at 248 ("These restrictions on the reach of Chevron create a great deal of complexity, and in a way that disregards the best justifications for the deference rule. The Court seems to have opted for standards over rules in precisely the context in which rules make most sense: numerous and highly repetitive decisions in which little accuracy is to be gained by a more particularized approach.").

191. Christensen v. Harris Cty., 529 U.S. 576, 587 (2000) (emphasis added). Justice Scalia dissented, arguing that Chevron Step Zero should be limited to a question of whether the challenged interpretation "represents the authoritative view of the Department of Labor", and, if so, then should be entitled to Chevron deference. Id. at 589 (Scalia, J., concurring in part and concurring in the judgment). In Christensen, Justice Scalia found sufficient the fact that the Solicitor of Labor cosigned the Solicitor General's brief that articulated the agency's statutory interpretation to establish that interpretation represented the agency's "authoritative view." Id. 
formal procedures. ${ }^{192}$ While Justice Thomas' majority opinion in Christensen provided no explanation for this revision of Chevron, ${ }^{193}$ Justice Breyer wrote separately in dissent to argue that the role of congressional intent as a justification for the initial, decidedly-unrevolutionary ${ }^{194}$ Chevron decision supports the narrowing of Chevron's domain "where one has doubt that Congress actually intended to delegate interpretive authority to the agency."

If Christensen can be read to "suggest[] a clean line between

192. Id. at 586-87 (majority opinion) ("In Chevron, we held that a court must give effect to an agency's regulation containing a reasonable interpretation of an ambiguous statute. Here, however, we confront an interpretation contained in an opinion letter, not one arrived at after, for example, a formal adjudication or notice-and-comment rulemaking." (citations omitted)).

193. Id. at 587-88. The paragraph explaining the majority's decision not to grant Chevron deference to the Department of Labor's interpretation provides no justification for this decision beyond citations to the following three cases: Martin v. Occupational Safety and Health Review Comm'n, 499 U.S. 144, 156-57 (1991), EEOC v. Arabian Am. Oil Co., 499 U.S. 244, 256-58 (1991), and Reno v. Koray, 515 U.S. 50, 61 (1995). In Martin, the court declined to grant deference to "agency "litigating positions" " because these interpretations "occur after agency proceedings have terminated" and thus "do not constitute an exercise of the agency's delegated lawmaking powers." Martin, 499 U.S. at 156. Justice Marshall's opinion, however, provided no explanation for why only statutory interpretations implemented through exercises of "the agency's delegated lawmaking powers" are entitled to receive Chevron deference, instead "emphasiz[ing] the narrowness of [the] holding" dealing "only with the division of powers between the Secretary and the Commission under the OSH Act." Id. at 157. In Arabian American Oil, Chief Justice Rehnquist's majority opinion applies Skidmore deference without addressing Chevron. Arabian American Oil, 499 U.S. at 25658. Justice Scalia's concurrence reads Rehnquist's opinion as relying upon a doctrinal anachronism granting minimal deference to the EEOC's statutory interpretations, a characterization the majority opinion does not expressly repudiate. Id. at 260 (Scalia, J., concurring in part and concurring in judgment). Finally, the language in Reno seems to run counter to the proposition for which Justice Thomas cites it; the relevant paragraph of Chief Justice Rehnquist's majority opinion cites Chevron to support the Court's application of "some deference" to BOP's interpretation. Reno, 515 U.S. at 61. See also Merrill \& Hickman, supra note 144, at 846 ("Unfortunately, the majority did not explain why having the force of law should mark the dividing line between interpretations entitled to Chevron deference and those entitled to Skidmore deference. The distinction was presented as a restatement of precedent but was not linked in any way to the underlying premises of the Chevron doctrine.").

194. Sunstein, supra note 65 , at $198-202$.

195. Christensen, 529 U.S. at 596 (Breyer, J., dissenting). Justice Thomas's reluctance to embrace Justice Breyer's emphasis on congressional intent as the mechanism for distinguishing the Chevron-eligible from the Chevron-ineligible may be read as a recognition of the complications accompanying such emphasis. While the "force of law" test provides a relatively clean bright line for determining Chevron eligibility, it may not be the most accurate indication of congressional intent, as the Court recognized a year later in United States v. Mead Corp., 533 U.S. 218, 230-31 (2001) ("[A]s significant as notice-and-comment is in pointing to Chevron authority, the want of that procedure here does not decide the case, for we have sometimes found reasons for Chevron deference even when no such administrative formality was required and none was afforded."). For the Supreme Court to follow the logic of Justice Breyer's dissent, as it will in Mead and Barnhart, infra notes 205 et seq., the Court would have to sacrifice the possibility of a bright line test in favor of a case-by-case approach. See Sunstein, supra note 65, at 208; Stephen Breyer, Judicial Review of Questions of Law and Policy, 38 ADMIN. L. REV. 363 (1986). 
Chevron cases and Skidmore cases, turning on the "force of law' test,"196 of which the agency's authority to act with formal procedures is a crucial indication, the Supreme Court's next foray into Chevron's domain significantly complicated the picture. Only a term later, the Supreme Court in Mead v. United States seemed to elevate to controlling law the Step Zero assessment of whether (1) Congress intended to delegate authority to the agency to interpret statutory ambiguities with agency actions "carrying the force of the law," "197 and (2) whether "the agency interpretation claiming deference was promulgated in the exercise of that authority." 198 This newfound emphasis on the role of congressional intent in Chevron deference closely tracks Justice Breyer's Christensen dissent, which the Mead court cited affirmatively ${ }^{199}$ and which commentators read as inspiring the Mead majority. ${ }^{200}$

By emphasizing the role of congressional intent in Chevron Step Zero and, perhaps more importantly, seeking to more closely approximate that intent, the Court in Mead blurred the boundaries demarcating Chevron's domain. Where the Christensen court seemed able to ask only whether the agency acted "with the force of law" Mead opinion is "best read" to permit "deference even when (a) an agency is not using formal procedures, and (b) an agency's actions lack the force of law" 202 so long as there exists some other relevant metric of congressional intent for agency's statutory interpretations to receive deference and the agency implemented the relevant interpretation in a manner that reflected Congress's intent. Mead purported to provide some of those other indicia of congressional intent: ${ }^{203}$ whether the agency promulgates the interpretation through "the legislative type of activity that would naturally bind more than the parties to the ruling", ${ }^{204}$ whether

\footnotetext{
196. Sunstein, supra note 65, at 216.

197. Mead, 533 U.S. at 226-27.

198. Id.

199. Id. at 230 (citing Justice Breyer's Christensen dissent for the proposition that "where it is in doubt that Congress actually intended to delegate particular interpretive authority to an agency, Chevron, is "inapplicable."').

200. Sunstein, supra note 65, at 214 (describing the majority's logic as "closely following Justice Breyer's position ....").

201. Christensen v. Harris Cty., 529 U.S. 576 (2000).

202. Sunstein, supra note 65 , at 216.

203. Mead, 533 U.S. at 231 ("The authorization for classification rulings, and Customs's practice in making them, present a case far removed not only from notice-and-comment process, but from any other circumstances reasonably suggesting that Congress ever thought of classification rulings as deserving the deference claimed for them here.").
}

204. Id. at 232 . 
the agency action "may be precedent in later transactions", ${ }^{205}$ whether there exist "provisions for independent review" of the action with which the agency promulgates the relevant interpretation, ${ }^{206}$ whether the agency "ever set out with a lawmaking pretense in mind", ${ }^{207}$ and whether the agency action is unique or one of " 10,000 to 15,000 of them each year.",208 The Mead majority provided little guidance for future courts to weigh these factors, as noted in Justice Scalia's dissent, ${ }^{209}$ requiring what amounts to a case-by-case examination of the totality of the circumstances to arrive at a judicial construction of congressional intent. $^{210}$

Justice Breyer's opinion for the Court in Barnhart v. Walton ${ }^{211}$

205. Id. The Court, however, notes that "precedential value alone does not add up to Chevron entitlement; interpretive rules may sometimes function as precedents [] and they enjoy no Chevron status as a class." Id.

206. Id. The existence of independent review in Mead seems to counsel against Chevroneligibility. Id. ("In any event, any precedential claim of a classification ruling is counterbalanced by the provision for independent review of Customs classifications by the CIT.").

207. Id. at 233 .

208. Id. Other factors, added in Mead's progeny, include whether the agency interpretation involves "unusually basic legal questions." Nat'l Cable \& Telecomms. Ass'n. v. Brand X Internet Servs., 545 U.S. 967, 1004 (2005) (Breyer, J., concurring). Never one to miss the opportunity to explicate his preferred understanding of Chevron, Justice Breyer provided further elucidation in his concurrence in City of Arlington v. FCC, 569 U.S. 290, 309 (2013). Justice Breyer noted the Mead force of law test, the Barnhart passage discussed infra notes 205 et seq., "the subject matter of the relevant provision-for instance, its distance from the agency's ordinary statutory duties or its falling within the scope of another agency's authority," "the statute's text, its context, the structure of the statutory scheme", and "legislative and regulatory history." Id. Justice Breyer acknowledges Justice Scalia's criticism of the case-by-case approach but argues such an approach best approximates "how Congress would likely have meant to allocate interpretive law-determining authority between reviewing court and agency." Id. at 310 .

209. Mead, 533 U.S. at 241 (Scalia, J., dissenting) ("The Court has largely replaced Chevron, in other words, with that test most beloved by a court unwilling to be held to rules (and most feared by litigants who want to know what to expect): th' ol' 'totality of the circumstances' test."); Barron \& Kagan, supra note 54, at 210-11 ("Though the opinion refrained from cataloguing these indicators, it suggested that chief among them is the degree of procedural formality involved in the action."). While procedural formality may provide something of a safe-haven, $i d$. at 214, agency's increasing reliance upon informal processes renders significant the question of judicial deference to agency interpretations promulgated through such means. Juan J. Lavilla, The "Good Cause" Exemption to Notice and Comment Rulemaking Requirements Under the Administrative Procedure Act, 3 ADMIN. L.J. 317, 339-40 nn.86-87 (1989).

210. Not inaccurately, Justice Scalia forecasted "protracted confusion." Mead, 533 U.S. at 245 (Scalia, J. dissenting). The majority's rebuttal noted that anything but a case-by-case approach would "declare[] irrelevant or minimize[]" the extensive "diversity of statutes authorizing discretionary administrative action." Id. at 236. The majority continued, "it is simply implausible that Congress intended such a broad range of statutory authority to produce only two varieties of administration action, demanding either Chevron deference or none at all." Id.

211. Barnhart v. Walton, 535 U.S. 212 (2002) solidified this development, rendering "the real [Step Zero] question" whether "Congress's (implied) instructions in the particular statutory scheme" demand deference to the agency's construction of an ambiguous statutory mandate or authorization. Sunstein, supra note 65 , at 218 . 
marked the apotheosis of this approach. ${ }^{212}$ Despite the fact that the Social Security Administration adopted a particular interpretation through "means less formal than 'notice and comment' rulemaking", ${ }^{213}$ Justice Breyer's majority opinion concluded that all the relevant factors indicated the SSA's interpretation was Chevron-eligible. ${ }^{214}$ The Barnhart and Mead majorities provided what amounts to a grab bag of indicators to determine whether Congress intended agencies' legal interpretations to receive deference, with only ambiguous connections between the indicators and congressional intent. ${ }^{215}$ Unsurprisingly, lower courts have taken the Supreme Court up on this offer, grasping inconsistently at the various considerations offered by the Barnhart and Mead courts. ${ }^{216}$ Studies of Step Zero in the circuit courts initially revealed courts' inability to reconcile Barnhart and Mead, ${ }^{217}$ with each circuit selecting one of either Barnhart or Mead to apply and thus binding the circuit to the approach embodied therein, ${ }^{218}$ followed by a general reluctance on the part of lower federal courts to resolve challenges to agency interpretations by reference to Step Zero. ${ }^{219}$ At best, then, the multi-factor analysis constituting Step Zero is an intellectual exercise so incoherent as to be ignored by lower courts, relevant only in the briefing of those rare challenges to agency interpretations adjudicated by the Supreme Court. ${ }^{220}$ At worst, Step Zero provides a grab bag in which courts may calibrate deference according to masked policy preferences. If the "genius of the Chevron doctrine" resides, as suggested by Professor Manning, in "its simplicity", ${ }^{221}$ there

212. Sunstein, supra note 65 at 216 (characterizing Barnhart as "Justice Breyer's triumph.”).

213. Barnhart, 535 U.S. at 221.

214. Id. Justice Breyer explained that "the interstitial nature of the legal question, the related expertise of the Agency, the importance of the question to administration of the statue, the complexity of that administration, and the careful consideration the Agency has given the question over a long period of time all indicate that Chevron provides the appropriate legal lens through which to view the legality of the Agency interpretation ...." Id. at 222.

215. But see Lisa Schultz Bressman, Reclaiming the Legal Fiction of Congressional Delegation, 97 VA. L. REV. 2009 (2011).

216. Bressman, How Mead has Muddled, supra note 71, at 1446; Sunstein, supra note 65, at 222; Adrian Vermeule, Introduction: Mead in the Trenches, 71 GEO. WASH. L. REV. 347, 347 (2003) (analogizing the D.C. Circuit's implementation of the Mead doctrine to "the line officers and soldiers who fought in the trenches at Verdun and the Somme [] put in an untenable position by generals who hadn't sufficiently accounted for the structural conditions of modern warfare").

217. See Bressman, How Mead has Muddled, supra note 71.

218. Id.

219. Kent Barnett \& Christopher J. Walker, Chevron in the Circuit Courts, 116 MICH. L. REV. 1, 69 (2017) (suggesting that the factors constituting Barnhart Step Zero's multi-factor analysis "may be doing silent work in the circuit courts' decisionmaking after a step-zero inquiry").

220. Id. at 67.

221. John F. Manning, Chevron and Legislative History, 82 GEO. WASH. L. REV. 1517, 1518 
cannot remain much genius in a doctrine that no longer provides a simple or even consistent answer to the question of when a reviewing court should defer to an agency's legal interpretation.

\section{Reimagining Chevron's Domain: Agency Independence}

To resolve the confusion created by the Chevron Step Zero trilogy, this Section argues for replacing the standards ${ }^{222}$ formulated in Mead, Christensen, Barnhart, and their progeny with a rule that conditions an agency's ability to access Chevron deference upon that agency's independence from presidential control. In so doing, courts should review with greater deference an executive agency's interpretation of a statute that Congress tasked that agency with implementing than an interpretation made by a similarly positioned independent agency. ${ }^{223}$ To advance this claim, this Section proceeds in three directions. First, it is necessary to mark the parameters of this reimagined Chevron Step Zero and define the relevant metrics of agency independence. Second, this Section makes the normative case for this approach, arguing that deference contingent upon agency independence better approximates

(2014).

222. While the vast rules-standards debate provides one avenue for criticizing existing Chevron Step Zero jurisprudence, an approach favored by Justice Scalia in his dissents and concurrences to the Step Zero trilogy, that is not the approach favored here. For more on the rules-standards debate, see generally Louis Kaplow, Rules Versus Standards: An Economic Analysis, 42 DukE L.J. 557 (1992); Cass R. Sunstein, Problems with Rules, 83 CALIF. L. Rev. 953 (1995); Kathleen M. Sullivan, The Justices of Rules and Standards, 106 HARV. L. REV. 22 (1992).

223. This proposal is not new. Outside the context of Chevron, Justice Breyer's dissent in FCC v. Fox, 556 U.S. at 547 , argued that courts should more closely review independent agency determinations. Randolph May twice argued for "differential deference", claiming concerns for political accountability should encourage courts to provide greater deference to executive agencies than to independent agencies. May, Defining Deference Down, supra note 69; May, Defining Deference Down, Again, supra note 69. Kagan, supra note 10 and Barron \& Kagan supra note 54, argue that deference should be contingent upon the level of presidential involvement in administration and, indeed, her arguments form the basis for the majority of May's claims. Professor Sharkey, supra note 49, argues for "harder look" review for independent agencies. See also David M. Gossett, Chevron, Take Two: Deference to Revised Agency Interpretations of Statutes, 64 U. CHI. L. REV. 681, 689 n.40 (1997) (noting that the "separation of powers" rationale for Chevron "would imply that independent agencies might not deserve Chevron deference"). None of these proposals, however, advance their claims in the context of Chevron Step Zero. Accordingly, this Article departs from prior proposals in arguing that (1) the delegatee-agency's degree of insulation from presidential control provides the best approximation of congressional intent regarding the allocation of what Justice Breyer calls "interpretive law-determining authority between reviewing court and agency," City of Arlington v. FCC, 569 U.S. at 310 (Breyer, J., concurring), and should thus replace the existing factors evaluated under Chevron Step Zero; and, (2) the primary justification for such a recalibrated deference regime lies not in the president as a source of political accountability, but rather the president as source of extra-statutory factors upon which agencies often rely. 
congressional intent, enhances political accountability, and encourages the exercise of agency expertise. Third, this Section surveys potential criticisms of this reformulated Step Zero, and responses to those criticisms. While there no doubt exists problems with the reformulated Step Zero proposed here, this approach better balances approximations of congressional intent, concerns for political accountability of administration, expertise-forcing, and judicial administrability than the current Step Zero.

\section{Defining Agency Independence}

Before advancing the normative case for differential deference ${ }^{224}$ contingent upon the degree of independence enjoyed by the agency receiving the relevant delegation, ${ }^{225}$ it is necessary to define and identify the appropriate level(s) of agency independence at which deference should be withheld. Despite the frequency with which independent agencies are invoked, neither courts ${ }^{226}$ nor scholars ${ }^{227}$ have settled upon a definition of agency independence. Without a clear definition, ideally endorsed by Congress given the centrality of congressional intent to Chevron deference, conditioning an agency's access to Chevron deference upon that agency lacking independence from the executive branch would replicate the confusion under Chevron Step Zero's existing multi-factor analysis.

Fortunately, Congress, in the Paperwork Reduction Act of $1980^{228}$

224. The phrase "differential deference" originates with May, Defining Deference Down, Again, supra note 69, at 440. Throughout, differential deference refers to distinct levels of deference contingent upon the relevant agency's independence, rather than, for example, deference contingent upon the reviewing court's place in the Article III hierarchy. See, e.g., Aaron-Andrew P. Bruhl, Hierarchically Variable Deference to Agency Interpretations, 89 NOTRE DAME L. REV. 727 (2013).

225. Hereinafter, the "delegate."

226. Compare PHH Corp. v. Consumer Fin. Prot. Bureau, 839 F.3d 1, 5-6 (D.C. Cir. 2016), vacated, reh'g en banc granted, 881 F.3d 75 (D.C. Cir. 2018) ("An agency is considered 'independent' when the agency heads are removable by the President only for cause, not at will, and therefore are not supervised or directed by the President.") with Free Enter. Fund v. Pub. Co. Accounting Oversight Bd., 561 U.S 477, 547 (2013) (Breyer, J., dissenting) (“Agency independence is a function of several different factors .... Those factors include, inter alia, an agency's separate (rather than presidentially dependent) budgeting authority, its separate litigating authority, its composition as a multimember bipartisan board, the use of the word 'independent' in its authorizing statute, and, above all, a political environment, reflecting tradition and function, that would impose a heavy political cost upon any President who tried to remove a commissioner of the agency without cause." (emphasis added)).

227. See generally Datla \& Revesz, supra note 66, at 772 (concluding that "[a]gencies cannot be neatly divided into two categories" but instead exist upon a continuum of independence evinced by a number of indicia); Vermeule, supra note 69, at 1174-75; Kagan, supra note 10, at 2376.

228. Paperwork Reduction Act of 1980, 44 U.S.C. § 3502(5) (2012). The Act allows 
("PRA"), provided a definitive list of independent agencies. ${ }^{229}$ While commentators have criticized Congress's list as imprecise, ${ }^{230}$ so long as the court primarily justifies Chevron deference by reference to congressional intent, only Congress's classifications of independent agencies hold relevance. Rather than weighing a number of factors that the court seems to recognize are only tangentially related to Congress's intended allocation of interpretive authority between administrative agencies and the judiciary, courts would grant Chevron deference only to those interpretations of statutes that Congress tasked an executive agency with implementing.

Even absent the clear statement of congressional intent contained in the PRA, it would be far easier for courts to derive Congress's intent to insulate an agency from presidential control in an authorizing statute-a real consideration of Congress's when creating new delegations ${ }^{231}$ - than it has been for courts to derive Congress's intent regarding the allocation of interpretive authority between courts and agencies ${ }^{232}$ - a legislative component that Congress is unlikely to consider much less authoritatively resolve. ${ }^{233}$ In other words, although both the factors

"independent regulatory agenc[ies]" with two or more members to override the OMB's informational request vetoes. 44 U.S.C. § 3507(f)(1) (2012).

229. In the Paperwork Reduction Act of 1980, Congress characterized the following agencies as independent: "the Board of Governors of the Federal Reserve System, the Commodity Futures Trading Commission, the Consumer Product Safety Commission, the Federal Communications Commission, the Federal Deposit Insurance Corporation, the Federal Energy Regulatory Commission, the Federal Housing Finance Agency, the Federal Maritime Commission, the Federal Trade Commission, the Interstate Commerce Commission, the Mine Enforcement Safety and Health Review Commission, the National Labor Relations Board, the Nuclear Regulatory Commission, the Occupational Safety and Health Review Commission, the Postal Regulatory Commission, the Securities and Exchange Commission, the Bureau of Consumer Financial Protection, the Office of Financial Research, Office of the Comptroller of the Currency, and any other similar agency designated by statute as a Federal independent regulatory agency or commission." 44 U.S.C. § 3502(5) (2012).

230. See, e.g., Datla \& Revesz, supra note 66, at 781, n.65.

231. Barkow, supra note 66, at 20.

232. Barnett \& Walker, supra note 219, at 66-67. Cf. Lisa Schultz Bressman, Reclaiming the Legal Fiction of Congressional Delegation, 97 VA. L. REV. 2009, 2050 (2011) [hereinafter Reclaiming the Legal Fiction] (arguing "there is direct evidence that Congress attends to the delegation of interpretive authority when it writes statutory language").

233. Eben Moglen \& Richard J. Pierce, Jr., Sunstein's New Canons: Choosing the Fictions of Statutory Interpretation, 57 U. CHI. L. REV. 1203, 1212-13 (1990) ("Like other interpretive regimes, the Supreme Court's approach in Chevron is premised on a series of fictions. The Court concluded that agencies should have the dominant role in interpreting ambiguous agency-administered statutes because: (1) Congress has delegated this power to agencies; and (2) the politically accountable President will control those policy decisions Congress has declined to make through his control over the agencies. Both premises are fictional in most cases.”). Cf. Bressman, Reclaiming the Legal Fiction, supra note 232, at 2050 ("The Court applies a presumption of legislative intent and draws an inference of legislative intent that corresponds to the political science account of how Congress 
composing the Mead/Barnhart analysis and the indicators of agency independence courts would evaluate absent the PRA approximate congressional intent, the latter notion of congressional intent exists whereas the former is widely-acknowledged as a legal fiction. ${ }^{234}$

\section{The Normative Defense}

The normative argument for conditioning Chevron eligibility on an agency's independence proceeds in the context of the three considerations identified as justifications for Chevron deference by the Chevron court and its successors. First, and most prominent given the development in the Supreme Court's justification for Chevron deference, ${ }^{235}$ is congressional intent. The Supreme Court recognizes that its multi-factor analysis under Chevron Step Zero intends only to approximate congressional intent regarding the allocation of interpretive authority between courts and agencies, and the delegatee-agency's independence provides a better approximation of congressional intent than do the factors upon which the court currently relies.

The Supreme Court has yet to provide any explanation for why its current multi-factor Step Zero analysis can accurately assess whether Congress sought to allocate greater "interpretive law determining power" to the agency tasked with implementing the relevant statute than to the judiciary. ${ }^{236}$ The question this proposal raises for Chevron Step Zero is whether the type of agency action with which the relevant agency implements its statutory authorization is a better approximation of Congress's delegation of interpretive authority than is the type of agency receiving the delegation. If, as argued in Section III.A, Chevron deference should be understood as a doctrine governing an agency's construction of the statutorily permissible factors for consideration, ${ }^{237}$

decides to delegate.").

234. Peter J. Smith, New Legal Fictions, 95 GEO. L.J. 1435, 1449-64 (2007).

235. See, e.g., all three opinions-Justice Scalia's majority, Justice Breyer's concurrence, and Chief Justice Robert's dissent-in City of Arlington v. FCC, 569 U.S. 290, 296 (2013); id. at 308-09 (Breyer, J., concurring); id. at 313-15 (Roberts, C.J., dissenting).

236. See Sunstein, supra note 65, at 196; Breyer, supra note 195, at 370, (characterizing the Chevron presumption as "a kind of legal fiction."). Recent empirical analysis of congressional drafting has attempted to supplement the Court's claims. See Bressman, supra note 232, at 2050; Gluck \& Bressman, supra note 188, at 994 ("Mead, despite abundant criticism, is more rooted in our respondents' drafting practice than any other canon in our study except perhaps Chevron."); Christopher J. Walker, Insider Agency Statutory Interpretation, 67 STAN. L. REV. 999, 1063 (2015).

237. Supra Section III.A, arguing this question is central, either explicitly or implicitly, to courts' application of Chevron Step Two. 
including extra-statutory factors such as presidential direction, ${ }^{238}$ then it follows that the degree of insulation from presidential control enjoyed by the agency receiving the relevant delegation indicates Congress's intentions regarding the President's capacity to dictate extra-statutory factors for the agency to consider when implementing its statutory authorization.

This claim relies upon the following two assumptions: (1) that Congress intends to subject executive agencies to greater presidential control than independent agencies, ${ }^{239}$ and (2) presidential direction is one prominent source of extra-statutory considerations. ${ }^{240}$ The second assumption, while not axiomatic in the manner of the first, finds considerable support in historical practice. Every presidential administration since Reagan has required that executive agencies perform cost-benefit analysis of all economically significant regulatory rules under consideration, ${ }^{241}$ so long as the delegating statute does not prohibit such analysis. ${ }^{242}$ That cost-benefit analysis is then subject to executive

238. Most prominently in Massachusetts v. EPA, 549 U.S. at 534-35 ("We need not and do not reach the question whether on remand EPA must make an endangerment finding, or whether policy concerns can inform EPA's actions in the event that it makes such a finding. Cf. Chevron U.S.A. Inc. v. Natural Resources Defense Council, Inc., 467 U.S. 843-844, 104 S.Ct. 2778, 81 L.Ed.2d 694, at $1 . ")$.

239. Humphrey's Ex'r v. United States, 295 U.S. 602, 628 (1935) (holding that independent agencies "cannot in any proper sense be characterized as an arm or an eye of the executive. Its duties are performed without executive leave and, in the contemplation of the statute, must be free from executive control."); Paul R. Verkuil, The Purposes and Limits of Independent Agencies, 1988 DUKE L. J. 257, 267-68 (1988); Barkow, supra note 66, at 17 . Even if presidential control of independent agencies has increased since the 1930s, most prominently in appointments and the development of independent agency's broader policy goals, see, e.g., Lisa Schultz Bressman \& Robert B. Thompson, The Future of Agency Independence, 63 VAND. L. REV. 599, 600 (2010); Neal Devins \& David Lewis, Not-So Independent Agencies: Party Polarization and the Limits of Institutional Design, 88 B.U. L. REV. 459, 459-60 (2008); Martin Shapiro, A Comparison of US and European Independent Agencies, in COMPARATIVE AdMINISTRATIVE LAW 293, 298 (Susan RoseAckerman \& Peter L. Lindseth eds., 2010); Vermeule, supra note 69, at 1203 (there indisputably remain powerful conventions of agency independence that restrict presidential direction of specific agency actions).

240. Datla \& Revesz, supra note 66, at 777 (arguing that, historically, independent agencies were intended "to allow the new agencies to focus on narrow subject areas without consideration of competing programmatic interests.”). Barkow, supra note 66, at 19-21.

241. President Reagan issued Executive Order 12,291, which established executive oversight, specifically vested in the Office of Information and Regulatory Affairs, of agency rulemakings based on cost-benefit analysis. Both Bush Administrations, the Clinton Administration, and Obama Administration maintained this basic structure. Exec. Order No. 12,291, 46 Fed. Reg. 13,193 (Feb. 17, 1981); Exec. Order No. 12,866, 58 Fed. Reg. 51,735 (Oct. 4, 1993); Exec. Order 13,563, 76 Fed. Reg. 3,821 (Jan. 21, 2011). See also Sharkey supra note 49, at 1620-21 (explaining that executive branch agencies "have been required by executive order to conduct cost-benefit analyses for most, if not all, of their economically significant rules since the Reagan Administration").

242. Whitman v. Am. Trucking Ass'ns, 531 U.S. 457 (2001) (holding that the Clean Air Act did not permit EPA to employ cost-benefit analysis when regulating). 
review by the Office of Information and Regulatory Affairs ("OIRA"), in effect introducing the President's assessment of a regulation's costs and benefits into agency decision-making. ${ }^{243}$ Quite literally, then, the President through executive order has mandated that agencies consider extra-statutory factors and, at least in the D.C. Circuit, an agency's reliance upon those executive orders provides sufficient justification for an administrative outcome. ${ }^{244}$ Indeed, the very premise of upon which proponents of presidential administration rely is that the president possesses the unique capacity to synchronize and energize administration through the introduction of extra-statutory factors for consideration. ${ }^{245}$

Operating under these assumptions, courts should assume a more deferential position toward executive agency's derivations of permissible factors for consideration than those of an independent agency to ensure that presidential direction has not altered an agency action over which Congress did not intend the President to exert control. Chevron deference provides the most significant mechanism with which courts facilitate presidential control of administration. ${ }^{246}$ Accordingly, courts should be reluctant to grant such deference to agencies Congress expressly sought to place outside the President's reach, especially so long as the Supreme Court justifies that deference primarily by reference

243. Caroline Cecot \& W. Kip Viscusi, Judicial Review of Agency Benefit-Cost Analysis, 22 GEO. MASON L. REV. 575, 582 (2015) (detailing the OIRA process for supervising executive agencies, including the process by which OIRA "ensures that the proposed regulations are consistent with president's overall policy objectives."). Claims that OIRA review provides the President with a mechanism for introducing political calculations into administrative processes dates back to the agency's formation. See, e.g., BREYER, supra note 41, at 69, (observing "charges that [OIRA] wields undue political influence" due to "the connection through OMB to the White House."). For more sympathetic portrayals of OIRA and the rise of cost-benefit analysis in the administrative state, see, e.g., CAss R. Sunstein, The Cost-Benefit State: The Future OF Regulatory Protection (2002).

244. Sherley v. Sebelius, 689 F.3d 776, 784 (D.C. Cir. 2012) (holding that "NIH [an agency of the Department of Health and Human Services] may not simply disregard an Executive Order."). Some scholars have, appropriately, criticized Sherley as standing for the proposition that an executive policy choice can insulate an agency from both the notice and comment process and judicial review of the substantive and procedural efficacy of that process. See Nicholas Bagley, Sherley You're Joking, NOTICE \& COMMENT (Mar. 22, 2017), http://yalejreg.com/nc/sherley-yourejoking/ [https://perma.cc/PV6S-NYK6]. Here, however, Sherley need only be read for the narrower proposition that within a range of statutorily permissible interpretations, the executive's policy preference may be dispositive. Dicta in Sherley supports this interpretation. Sherley, 689 F.3d at 784 ("[A]s an agency under the direction of the executive branch, $[\mathrm{NIH}]$ must implement the President's policy directives to the extent permitted by law." (emphasis added)).

245. Kagan, supra note 10, at 2339.

246. Cass R. Sunstein, Beyond Marbury: The Executive's Power to Say What the Law Is, 115 YALE L.J. 2580, 2581 (2006) ("[T] interpretation, above all in Chevron."); Watts, Proposing a Place, supra note 15. Kagan, supra note 10 , at 2372 . 
to congressional intent.

Second is the concern for political accountability that initially appeared to motivate the Chevron doctrine. ${ }^{247}$ To the extent that the Supreme Court still finds an agency's political accountability relevant to provision of deference to that agency's legal determinations, ${ }^{248}$ conditioning the provision of that deference upon an agency's insulation from presidential control would better promote a politically accountable administration. Conditioning deference in this way facilitates presidential control of executive agency decisions and congressional control-in the form of adherence to an agency's statutory mandate or authorization - of independent agencies. ${ }^{249}$ Justice Scalia's plurality opinion in Fox contests this claim, arguing that independent agencies are just as politically accountable as executive agencies albeit to Congress rather than the President. ${ }^{250}$

The logic of Justice Scalia's Fox plurality fails to compel. First, the available empirical evidence indicates that an agency's independence from presidential control does not correspond to enhanced congressional oversight. $^{251}$ Second, Congress, unlike the executive branch with a single President atop the institutional hierarchy, ${ }^{252}$ is a disparate body

247. Supra Section III.A.

248. Compare supra Section II.A with Lisa Schultz Bressman \& Michael P. Vendenbergh, Inside the Administrative State: A Critical Look at the Practice of Presidential Control, $105 \mathrm{MICH}$. L. REV. 47, 83 (2006) (arguing that White House involvement in administration "may not promote much political accountability in a functional sense - that is, with the aim of ensuring that regulatory activity reflects public preferences and resists narrow influences.").

249. Gossett, supra note 223, at 689 n.40 (noting the political accountability or "Separation of Powers" rationale "would imply that independent agencies might not deserve Chevron deference ...."); David E. Lewis \& Jennifer L. Selin, Political Control and the Forms of Agency Independence, 83 GEO. WASH. L. REV. 1487, 1515 (2015).

250. FCC v. Fox TV Stations, Inc., 556 U.S. 502, 524 (2009).

251. Brian D. Feinstein, Designing Agencies for Congressional Control, 69 ADMIN. L. REV. 259, 259, 276 (2017) (arguing that independent agencies, which Feinstein defined as agencies containing "fixed terms for appointees and statutory mandates on appointee qualifications", "appear to be more independent of congressional as well as presidential control, contrary to a conventional wisdom that they tend to reflect Congress's preferences.").

252. Kagan, supra note 10, at 2255; CALABRESI \& YoO, supra note 86, at 3; Lawrence Lessig \& Cass R. Sunstein, The President and the Administration, 94 ColuM. L. REV. 1, 2-3 (1994). But see Jennifer Nou, Agency Self-Insulation Under Presidential Review, 126 HARV. L. REV. 1755, 1761 (2013) (arguing that presidential direction of administration emerges from more diffuse sources than proponents of the unitary executive believe due to the President's delegation of regulatory review). Even if Professor Nou's account of agency self-insulation casts some doubt on the unitary nature of presidential oversight of regulation, power in the Executive branch remains significantly more centralized than in Congress, which Nou acknowledges "has effectively abdicated the monitoring of its initial delegations of power." Id. at 1764 (citing Mathew D. McCubbins \& Thomas Schwartz, Congressional Oversight Overlooked: Police Patrols Versus Fire Alarms, 28 AM. J. POL. SCI. 165, $166(1984))$. 
with oversight powers allocated to different committees across both the House and Senate, ${ }^{253}$ rendering congressional control a less direct and thus less effective instrument of political accountability than presidential control. Third, to the extent that congressional control of independent agencies is both possible and desirable, ${ }^{254}$ the available mechanisms by which Congress may control independent agencies quite simply do not facilitate political involvement in administrative processes as effectively as presidential control in the form of, for example, OIRA review. Congress may set the terms under which administrative rulemaking and adjudication occur but lacks the capacity to exert control over either process once underway. ${ }^{255}$

Ex ante congressional controls, ${ }^{256}$ implemented legislatively in the form of mandatory delegations and "hard-wiring" of agencies procedural requirements or structural modifications, ${ }^{257}$ dictate the terms on which agency decision-making occurs, but cannot stop the process once set in motion. Further, ex ante controls are best enforced through heightened judicial scrutiny of independent agency decision-making. Less deferential judicial review of independent agencies' interpretive decisions constitutes perhaps the most significant mechanism by which courts may encourage ex ante congressional control of administration to the extent that such review facilitates a closer adherence to the relevant delegating statutes and legislatively mandated procedures. ${ }^{258}$ Ex poste congressional controls such as appropriations riders, ${ }^{259}$ seek to control agency action in enforcement proceedings after the rulemaking process has been completed but, again, cannot dictate the outcome of an

253. Jamelle C. Sharpe, Judging Congressional Oversight, 65 ADMIN. L. REV. 183, 187 (2013) (arguing that Congress' ability to supervise administration is severely impeded by "collective action problems, information deficits, and only episodic interest in bureaucratic affairs. Complete delegation, as currently conceived and applied by the courts, makes legislators' task of managing agency slack that much more difficult.”); Kagan, supra note 10, at 2259-60.

254. Macey, supra note 127; Beermann, Congressional Administration, supra note 127, 72, n. 38 .

255. Sierra Club v. Costle, 657 F.2d 298 (D.C. Cir. 1981), legitimated communications between legislators and EPA in the rulemaking process, but only so long as those communications expressed the interests of an individual legislator's constituents, rather than Congress as a whole. The Costle court stated "[w]e believe it entirely proper for Congressional representatives vigorously to represent the interests of their constituents before administrative agencies engaged in informal, general policy rulemaking, so long as individual Congressmen do not frustrate the intent of Congress as a whole as expressed in statute, nor undermine applicable rules of procedure." Id. at 409 (emphasis added).

256. Beermann, Congressional Administration, supra note 127, at 72.

257. Id.

258. Id. at 71 ("Congress's most important formal method of influencing the administration of law is legislation...").

259. Id. at 72, n. 38 . 
administrative process. In short, because there exists no evidence that Congress passes more legislation controlling independent agencies than executive agencies, ${ }^{260}$ congressional control of independent agencies does not provide political accountability in administration remotely comparable to that provided by the exertion of presidential control over executive agencies.

By granting deference only to statutory interpretations promulgated by executive agencies, this reformulated Chevron Step Zero would better facilitate politically accountable administration in those agencies which Congress sought to render politically accountable. Simultaneously, this rule governing the grant of deference would subject the interpretations of those agencies that Congress sought to insulate from presidential control to more rigorous review to ensure those independent agencies considered only the apolitical factors Congress statutorily prescribed. In both Chevron's application and its denial, then, courts would encourage political accountability in administration through the appropriate, congressionally-selected mechanism: either executive or statutory control. While statutory control remains relevant, of course, for executive agencies under Chevron Step Two, ${ }^{261}$ courts' responsibility to hold independent agencies, lacking an alternative source of political accountability, to their statutory mandates would take on a greater significance $^{262}$ in this reformulated Step Zero. The statute as the primary source of political control is, axiomatically, even more true in the context of Chevron and statutory interpretation conducted by independent agencies than in the broader context of arbitrary and capricious review, where Justice Scalia claimed independent agencies remain subject to other forms of political control. ${ }^{263}$

Third, and less prominent but still present in the Chevron court's justification for its deference to agency legal determinations, are concerns for the promotion of the exercise of agency expertise. While this justification for Chevron deference has been largely absent from the court's recent Chevron Step Zero analysis, ${ }^{264}$ a reformulated Step Zero

\footnotetext{
260. Feinstein, supra note 251.

261. Supra Section III.A.

262. David Epstein and Sharyn O'Halloran advance a related claim in DELEGATING POWER: A TRANSACTION COST POLITICS APPROACH TO POLICY MAKING UNDER SEPARATE POWERS 57-58 (1999) (demonstrating that congressional delegations contain more specific mandates during periods of divided government to minimize the discretion afforded to the implementing authority).

263. In Fox, Justice Scalia identified congressional committee oversight as ensuring Congress maintained control over the FCC's decision. FCC v. Fox TV Stations, Inc., 556 U.S. 502, 523-26 (2009).

264. See, e.g., both Justice Scalia's majority opinion and Chief Justice Roberts' dissent in City
} 
analysis that conditions deferential review upon an agency's independence would facilitate the exercise of agency expertise for those questions that Congress sought to be determined by apolitical technocracy, while leaving room for agencies to consider political factors when implementing those statutory authorizations that Congress delegated to agencies under executive control. ${ }^{265}$ The threat of a more searching judicial review for those agencies that Congress intended to be most technocratic would discourage presidential direction of an independent agency's interpretive actions. ${ }^{266}$

Finally, and prominent in Justice Scalia's objections to Chevron Step Zero, ${ }^{267}$ are questions of judicial administrability. The Supreme Court's application of Chevron Step Zero provides little guidance for lower courts in determining whether a particular agency action warrants deference, ${ }^{268}$ and lower courts have tended to avoid the question rather than reconcile the Supreme Court's perplexing jurisprudence. ${ }^{269}$ Conditioning Chevron deference upon the independence of the agency receiving the delegation, however, would pose few problems for lower courts to administer. ${ }^{270}$ Indeed, the straightforward analysis under the reformulated Step Zero proposed here would ask only: (1) is the statute being interpreted one that the agency is tasked with implementing, and (2) is the interpretation promulgated by an executive agency in the implementation of that statute? While approximating congressional

\footnotetext{
of Arlington v. FCC, 569 U.S. 290 (2013). Justice Breyer appears far more cognizant of agency expertise as a relevant consideration, but only as one of many potentially relevant factors. See, e.g., Barnhart v. Walton, 535 U.S. 212, 222 (2002) (listing "the related expertise of the Agency" as one of many factors in determining whether the Court should deferentially review the agency's statutory interpretation); City of Arlington, 569 U.S. at 311 (Breyer, J., concurring) (granting Chevron deference because, inter alia, "the provision concerns an interstitial administrative matter, in respect to which the agency's expertise could have an important role to play; and ... the matter, in context, is complex, likely making the agency's expertise useful in helping to answer the 'reasonableness' question that the statute poses.").

265. Barkow, supra note 66, at 19; May, Defining Deference Down, supra note 67, at 445.

266. While it is also likely that independent agencies, assumed by both scholars and courts to possess greater "expertise" than executive agencies, Barkow, supra note 66, at 19 , could employ that expertise to derive additional logically-relevant extra-statutory considerations when interpreting a statutory authorization, such considerations would survive heightened judicial scrutiny to the extent that they are indeed logically-relevant to the implementation of the agency's statutory authorization. This is particularly true when that heightened judicial scrutiny would be aimed at improper presidential involvement.

267. United States v. Mead Corp., 533 U.S. 218, 240-41 (2001) (Scalia, J., dissenting).

268. Sunstein, supra note 65.

269. Bressman, How Mead has Muddled, supra note 71, at 1491.

270. Even if there exists significant scholarly debate about the precise definition of an independent agency, courts should consider congressional designations dispositive when the aim is to approximate congressional intent.
} 
intent and promoting politically accountable administration, neither of these questions raises the often irresolvable and highly-court dependent ${ }^{271}$ determinations required under Mead.

\section{Counterarguments}

The following subsection addresses the counterarguments, both doctrinal and normative, that may be marshalled against the reformulated Step Zero proposed here. First, and the strongest criticism of the reformulated Step Zero that animates Justice Breyer's multi-factor test, are claims that only a case-by-case multi-factor approach can best capture the subtle variations in congressional intent. ${ }^{272}$ Applied to the reformulated Step Zero, this claim asks whether some agencies, even in implementing a single authorizing statute, may promulgate both interpretations to which Congress prefers courts defer and interpretations to which Congress prefers courts closely scrutinize.

Even if the multi-factor test that the Supreme Court currently employs better approximates the range of delegations that Congress may utilize, ${ }^{273}$ lower courts' difficulty administering the multi-factor test undermines the precision of those approximations. ${ }^{274}$ Especially given the Supreme Court's limited oversight ability due to its restricted caseload, ${ }^{275}$ clearer rules for lower courts to apply are particularly important. When Mead is accurately understood to be an attempt by the Supreme Court to "try[] to affect congressional behavior"276 as a reflection of congressional intent, Mead's proponents will struggle to argue that the doctrine's precision in approximating congressional intent justifies difficulties in implementation. ${ }^{277}$

At the circuit court level, these barriers to implementation undermine the subtlety of the markers of congressional intent the Supreme Court employs in Barnhart. One comprehensive study of Chevron at the circuit level found the "largescale absence [of Barnhart and other

\footnotetext{
271. Bressman, How Mead has Muddled, supra note 71, at 1491.

272. Supra notes 197-99 (Breyer's concurrence in Mead).

273. Id.

274. Bressman, How Mead has Muddled, supra note 71, at 1491.

275. See David R. Stras, The Supreme Court's Declining Plenary Docket: A Membership-Based Explanation, 27 CONST. COMmENT. 151, 152 (2010) (noting the "extraordinary" decline in the Supreme Court's plenary docket).

276. Abbe R. Gluck, What 30 Years of Chevron Teach Us About the Rest of Statutory Interpretation, 83 FORDHAM L. REV. 607, 624 (2014).

277. See Barron \& Kagan, supra note 54, at 223.
} 
contextual factors] from deference discussions in the circuit courts."278 The fact that circuit courts decline to employ the multi-factor analysis under Barnhart, preferring the "the relatively more rule-like certainty of Mead", ${ }^{279}$ demonstrates the following. First, that existing Step Zero doctrine may only claim to constitute a superior approximation of congressional intent in the miniscule minority of Chevron cases decided at the Supreme Court. Second, the Supreme Court's pursuit of ever more precise approximations of congressional intent amounts to little more than an intellectual exercise. Further, and perhaps partially animating the circuit courts' reluctance to apply Barnhart's multi-factor analysis, the binary nature of Chevron deference ${ }^{280}$ renders Chevron a particularly poor delivery vehicle for a carefully-calibrated deference scheme. In other words, a doctrine highly responsive to distinctions in degrees of delegated authority that then only applies, or declines to apply, a blanket level of deference undermines the doctrine's own claim to precision. A blanket presumption, which much of the court still understands Chevron to be, functions better when applied by bright-line. ${ }^{281}$

Second, and perhaps an indication of the doctrine's incoherence, some scholars have attempted to reclaim Chevron Step Zero from Chevron, finding justifications for the doctrine's development in areas of law and policy beyond the question of judicial deference to agency's statutory interpretations. Proponents of a clear(er) distinction between legislative and non-legislative rules have argued that Mead and Barnhart mark a significant step towards a judicially-recognized definition of

278. Barnett \& Walker, supra note 219 , at 70.

279. Id. (noting circuit courts curious refusal of the discretion provided by the "ad-hoc approaches before Chevron or offered by Barnhart" that would "better hide strategic decisionmaking", in favor of the Mead rule: "circuit courts seem to have found some benefits in having others limit their agency").

280. Perhaps now tri-partite, with the possibility of no deference, Skidmore deference, or Chevron deference. See supra Section III.A.

281. Mead alone remains an inferior bright-line than the agency independence indicia proposed here. Mead's force of law test is both over- and under-inclusive. Mead is over-inclusive because Congress might wish for an agency to issue binding rules but still be subjected to de novo review of any interpretations of ambiguous terms made in the course issuing those binding rules. Indeed, the APA's "provision on judicial review permits this division," signaling that "Congress must have contemplated... some division of substantive lawmaking authority from interpretive authority." Kagan \& Barron, supra note 54, at 218. Simultaneously, however, Mead is under-inclusive because Congress might seek to grant interpretive authority to an agency even if that agency lacks the power to issue binding rules. Id. at 219. Even if an agency's independence is a similarly imperfect approximation insofar as it is possible to conceive of a congressional delegation that intended to grant interpretive authority to an independent agency, an agency's independence directly signals the degree to which Congress sought to insulate that agency from the president as source of extrastatutory factors for consideration and Chevron most fundamentally concerns an agency's derivation of the factors upon which that agency may rely in support of an administrative outcome. 
nonlegislative rules as nonbinding in practice. This argument suggests Mead and Barnhart resolved the complex judicial debates about the distinction between legislative and non-legislative rules, rendering nonlegislative rules "nonbinding in practice" and thereby enshrining in doctrine the view that only rules issued under notice and comment are legally binding. ${ }^{282}$ The general difficulty scholars have had in justifying Mead and Step Zero on its own terms has encouraged the serious treatment of this claim, ${ }^{283}$ but proponents of this justification for Mead have yet to resolve the 'severability' problem. Even if Mead implies certain desirable doctrinal outcomes outside the context of Chevron, there is little reason those desirable outcomes cannot remain doctrine while the Court consigns Mead itself to the dustbin. To the extent that Mead serves other purposes that would be undermined by a reformulated Chevron Step Zero, the previous objections to Mead make clear that the Chevron doctrine is an inappropriate site for such a doctrinal development. ${ }^{284}$ Further, there remains significant disagreement about whether courts should universally treat any rule that has not gone through notice and comment as nonlegislative and thus not legally binding. ${ }^{285}$

Third are concerns for precedent. While the reformulated Step Zero no doubt would amount to a significant departure from precedent, there exist two relevant doctrinal hooks. As an initial matter, Justice Breyer's multifactor test implementing Chevron Step Zero, which is most likely

282. John F. Manning, Nonlegislative Rules, 72 GEO. WASH. L. REV. 893, 940 (2004); Jacob E. Gersen, Legislative Rules Revisited, 74 U. CHI. L. REV. 1705, 1720-21 (2007).

283. David L. Franklin, Legislative Rules, Nonlegislative Rules, and the Perils of the Short Cut, 120 YALE L.J. 276 (2010). Franklin advances three arguments. First, Mead creates only a presumption that non-legislative rules are ineligible for Chevron deference, meaning Mead fails to implement any bright-line on the non-binding effect of non-legislative rules as demonstrated in Barnhart v. Walton, 535 U.S. 212 (2002). Id. at 320. Second, because nonlegislative rules would still receive Skidmore deference, the claim that they become "nonbinding in practice", Manning, supra note 282, at 940, is inaccurate because Skidmore deference may still be quite deferential. Id. at 321. Third, Mead does little to prevent agencies receiving deference under Bowles v. Seminole Rock \& Sand Co., 325 U.S. 410 (1945), for non-legislative rules interpreting their own regulations. Id. at 323-24.

284. This claim-"right outcome, wrong mechanism"-responds to a related reclamation of Mead, made by Professor Gluck, supra note 276, at 623-25, arguing that Mead provided an "end run around" Vt. Yankee Nuclear Power Corp. v. Nat'l Res. Def. Council, Inc., 435 U.S. 519 (1978), which held that federal courts could not add procedural requirements beyond those specified in the APA to agency statutory implementation. Professor Gluck argues Mead "accomplishes close to the same result [of allowing federal courts to add procedural requirements beyond those set forth in the APA] in a more indirect fashion, encouraging agencies to use formal procedures if they want their interpretations to get deference." Gluck, supra note 276, at 624 .

285. Compare, Franklin, supra note 283, at 324-25 with Manning, supra note 282 and Gersen, supra note 282. 
controlling, ${ }^{286}$ includes an assessment of the delegatee-agency's characteristics, including independence. ${ }^{287}$ Accordingly, the reformulation requires only heightening the emphasis placed on this factor, a process for synthesizing and simplifying multifactor tests with which the Court possesses extensive familiarity. ${ }^{288}$ Should the Court maintain the Mead/Barnhart multifactor Step Zero analysis, this Article more modestly argues courts should consider an agency's independence as a significant or even dispositive factor in whether Chevron should apply, particularly for those decisions implicating an agency's reliance upon extra-statutory political factors.

Moreover, the fact that Justice Breyer's Fox dissent, applying heightened scrutiny to independent agency action, ${ }^{289}$ commanded as many votes as Justice Scalia's plurality expressly rejecting stricter review for independent agencies ${ }^{290}$ evinces the existence of nearsufficient support for conditioning deference upon agency independence. ${ }^{291}$ While Chevron went unreferenced in Fox, ${ }^{292}$ Justice Scalia and Justice Breyer's opinions diverged on Chevron's initial justification: the extent to which an agency's political accountability should implicate the rigor of judicial review of that agency. ${ }^{293}$ The concerns animating Chevron have no doubt evolved over the past three decades, ${ }^{294}$ consolidating around the likely fictitious claim to

286. Supra notes 211-19 (discussing Barnhart).

287. City of Arlington v. FCC, 569 U.S. 290, 309 (2013) (Breyer, J., concurring) (noting that the agency's expertise in administering a complex matter weighs in favor of deference).

288. See, e.g., the evolution in the Court's doctrine governing the recognition of implied private rights of action. The Court narrowed its analysis from the four factors presented by Justice Brennan in Cort v. Ash, 422 U.S. 66 (1975) to the single question of congressional intent. See, e.g., Alexander v. Sandoval, 532 U.S. 275 (2001).

289. FCC v. Fox, 556 U.S. 502, 547 (2009).

290. Id. at 523 .

291. Indeed, in some regards the conditional deference for which Justice Breyer's Fox dissent advocates a more radical doctrinal departure than that advocated here; Breyer's Fox dissent addresses independent agency action generally, and not just in the relatively narrow domain of agency's interpretations of statutes. Fox, 556 U.S. at 547. While it is to this reading of Justice Breyer's Fox dissent that Justice Scalia's plurality responds, id. at 523, Breyer's dissent need not be read as a call for heightened scrutiny, depending on one's gloss of "all the more important." Id. at 547 (Breyer, J., dissenting).

292. Id.

293. May, Defining Deference Down, Again, supra note 69, at 448. But see, Enrique Armijo, Politics, Rulemaking, and Judicial Review: A Response to Professor Watts, 62 ADMIN. L. Rev. 573, 581 (2010). Of course, Chevron governs one area of substantive arbitrary and capricious review, supra Section III.A, implying that if extra-statutory considerations provide sufficient support, according to at least four Justices, for a particular agency action under a less deferential form of review than Chevron, extra-statutory considerations may control Chevron-eligible interpretations, as well.

294. This development renders May's claims less powerful than if they had been advanced in 
approximate congressional intent, ${ }^{295}$ but the Fox opinions remain relevant so long as the Chevron prudential considerations hold any sway. ${ }^{296}$

\section{CONCLUSION}

As opposed to the law governing the sufficiency of an agency's procedures for arriving at an administrative outcome, substantive administrative law-governing the sufficiency of an agency's justifications for that outcome-is most fundamentally a matching exercise. The reviewing court decides if the set of justifications the agency provided reflect the factors that Congress intended the agency to consider when implementing the relevant statutory authorization. In this way, judicial review of agency reason giving most frequently takes the form not of an assessment of the technical merits of the decision, but instead a demarcation of the factors an agency may consider followed by a determination of whether the reasons supplied reside within that set of permissible factors. The doctrinal development in Chevron was to formalize and, at least initially, universalize the presumption that an agency's statutorily derived reasons for acting aligned with the reasons upon which Congress intended the agency to act. Instead of interpreting the aims of a relevant statute and deriving congressional intent regarding permissible factors for consideration, post-Chevron courts presumptively accept agencies' statutory derivations of the permissible reasons an agency may provide in support of an administrative outcome.

Over the three and a half decades that followed, the Court pursued increasingly elusive notions of congressional intent, developing a set of conditions detailing the type of agency action in review of which courts would apply this presumptive deference. To the extent that this presumptive deference provides meaningful freedom for agencies to derive permissible factors for consideration, the set of conditions upon which access to that deference hinges become the parameters of

the years immediately following Chevron when prudential concerns for political accountability rather than interpretive fictions of congressional intent animated the Court's deference doctrine.

295. Supra Section III.A. But see Bressman, supra note 232; Gluck \& Bressman, supra note 188. The implications of Professors Gluck and Bressman's study for Chevron are complex; while Gluck and Bressman reported a significant majority of the surveyed congressional staffers were familiar with Chevron (82\%), id. at 995-96, for the majority of the surveyed staffers, "Chevron does not appear to have increased the likelihood of ambiguity or its use as an additional signal that drafters were not using before the Court's decision .... Chevron itself does not seem to be a typical reason for ambiguity." Gluck \& Bressman, supra note 188, at 997.

296. Watts, supra note 98 , at 731 . 
administrative reason giving. So long as an agency acted under those conditions, reviewing courts would defer to the agency's derivation of the reasons supplied and often, therefore, to the administrative outcome.

Prescriptively, this Article sought to demonstrate that the set of conditions under which courts grant deference to, in effect, agency reason giving are divorced from concerns for both politically accountable and expert administration. Rather than attempt to approximate what even the doctrine's creators have acknowledged to be a fictitious notion of congressional intent with increasing nuance, the Court should adopt a bright line rule granting deference to executive agencies' derivation of permissible factors for consideration but denying such deference to independent agencies' statutory interpretations. The benefits of such a rule are twofold. First, this rule acknowledges the preeminent role of the President in controlling the administrative state through the President's ability to dictate the extra-statutory factors an agency must consider when acting and thereby promote politically accountable administration. Second, this rule ensures that those decisions Congress delegated to independent agencies are made according to the agency's technical expertise exercised free from political pressure. More modestly formulated, this Article suggests that courts consider directly the implications for administrative reason giving of the various deference doctrines; such consideration may encourage a rethinking of the conditions under which agencies' legal interpretations receive deference. 